Review

\title{
Cyanobacterial Cyclopeptides as Lead Compounds to Novel Targeted Cancer Drugs
}

\author{
Ioannis Sainis ${ }^{1}$, Demosthenes Fokas ${ }^{2}$, Katerina Vareli ${ }^{1,3}$, Andreas G. Tzakos ${ }^{1,4}$, Valentinos \\ Kounnis ${ }^{5}$ and Evangelos Briasoulis ${ }^{1,5, *}$
}

1 Human Cancer Biobank Center, University of Ioannina, Greece; E-Mails: isainis@cc.uoi.gr (I.S.); kvareli@cc.uoi.gr (K.V.); atzakos@cc.uoi.gr (A.T.)

2 Department of Materials Science and Engineering, University of Ioannina, Greece; E-Mail: dfokas@cc.uoi.gr (D.F.)

3 Department of Biological Applications and Technologies, University of Ioannina, Greece

4 Department of Chemistry, University of Ioannina, Greece

5 School of Medicine, University of Ioannina, Greece; E-Mail: vkounnis@cc.uoi.gr (V.K.)

* Author to whom correspondence should be addressed; E-Mail: ebriasou@cc.uoi.gr or ebriasou@me.com; Tel.: +30-265-100-7713; Fax: +30-265-100-8087.

Received: 4 January 2010; in revised form: 10 February 2010 / Accepted: 26 February 2010 / Published: 15 March 2010

\begin{abstract}
Cyanobacterial cyclopeptides, including microcystins and nodularins, are considered a health hazard to humans due to the possible toxic effects of high consumption. From a pharmacological standpoint, microcystins are stable hydrophilic cyclic heptapeptides with a potential to cause cellular damage following uptake via organic aniontransporting polypeptides (OATP). Their intracellular biological effects involve inhibition of catalytic subunits of protein phosphatase 1 (PP1) and PP2, glutathione depletion and generation of reactive oxygen species (ROS). Interestingly, certain OATPs are prominently expressed in cancers as compared to normal tissues, qualifying $\mathrm{MC}$ as potential candidates for cancer drug development. In the era of targeted cancer therapy, cyanotoxins comprise a rich source of natural cytotoxic compounds with a potential to target cancers expressing specific uptake transporters. Moreover, their structure offers opportunities for combinatorial engineering to enhance the therapeutic index and resolve organ-specific toxicity issues. In this article, we revisit cyanobacterial cyclopeptides as potential novel targets for anticancer drugs by summarizing existing biomedical evidence, presenting structure-activity data and discussing developmental perspectives.
\end{abstract}


Keywords: microcystin; cyanobacteria; cyanotoxins; cancer; targeted-therapy; OATP; membrane transporters

\section{Introduction}

Cyanobacteria (blue-green algae) appeared approximately 3.5 billion years ago, triggering major ecological change through photochemical release of molecular oxygen from water into the atmosphere [1,2]. The cyanobacteria population comprises 150 genera and about 2000 species of considerable diversity. They are prokaryotic algae that exist as unicellular species or in colonies (Figure 1). Due to their photosynthetic capacity, they constitute the primary first level organisms in food chains in water ecosystems. Moreover, these prokaryotes play a significant role in the marine nitrogen cycle and also have a role in balancing nitrogen $(\mathrm{N})$ and $\mathrm{CO}_{2}$ dynamics in the biosphere [3] Besides their life-sustaining role, the eutrophic growth of certain species of cyanobacteria in water reservoirs (toxic cyanobacterial water-blooms) have generated increasing concerns for human and animal health due to the detrimental effects of the toxins they produce [4-7]. Therefore, regular monitoring of suburban water reservoirs for cyanotoxins has become a necessity and is encouraged [8,9]. In the case of humans, the prime cyanobacterial toxicoses are acute liver damage, neurotoxicity, gastrointestinal disturbances and liver cancer, all of which demonstrate the potent biological activity of cyanotoxins [10,11]. However, from a pharmacological point of view, the targeted biological activities and characteristic physicochemical properties of cyanotoxins identify these molecules as potent candidates that warrant pharmacological exploitation as targeted cancer therapeutics. More specifically, cyanobacterial cyclopeptides share a pharmacophore structure that may lead to development of a novel class of anticancer therapeutics with activity against chemotherapy-refractory metastatic cancers that express organic anion transporters, the primary molecular targets of these compounds $[12,13]$. In this article, we focus on microcystin (MC) as a potential anticancer compound and present relevant supporting data.

Figure 1. Typical colony-forming cyanobacteria found in a toxic bloom in a Mediterranean lake (Lake Pamvotis Greece). A. Anabaena sp. B. Microcystis sp.

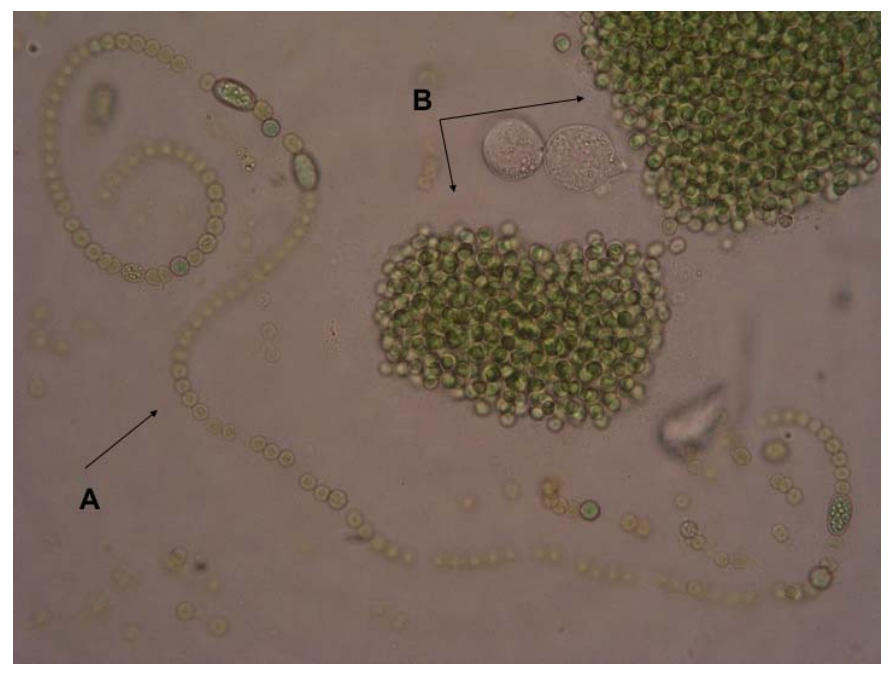




\section{Cyanotoxins-Microcystin}

\subsection{Categories}

Cyanobacterial toxins (cyanotoxins) belong to diverse chemical classes and can cause cell-specific toxicity such as neurotoxicity by anatoxin-a, anatoxin-a(S) and saxitoxins; hepatotoxicity by microcystins, nodularin and cylindrospermopsin; and dermatitis by lyngbyatoxin-a [14]. Among cyanotoxins, the cyclic cyanotoxins nodularins and $\mathrm{MC}$ are among the most common natural toxins. They have been well studied and have been shown to share similar mechanisms of biochemical action. Both are potent inhibitors of the serine/threonine protein phosphatase families PP1 and PP2A and also pro-oxidants with a potency to induce cell damaging oxidative stress through generation of reactive oxygen species (ROS) $[15,16]$.

\subsection{Microcystins: Physicochemical Characteristics}

Microcystins (MC) are cyclic heptapeptides with a relative molecular mass $\left(\mathrm{M}_{\mathrm{r}}\right)$ varying between 500 and $4000 \mathrm{Da}$. They were first isolated from a strain of Microcystis aeruginosa and named after this organism. High MC content has also been found in other species such as Anabaena, Planktothrix, Nostoc, Anabaenopsis, Aphanocapsa and in the soil cyanobacterium Haphalosiphon. The MCs comprise a series of more than 60 cyclic heptapeptides with the general structure cyclo-(D-Ala-X-(D)erythro- $\beta$-methyl-iso-Asp-Y-Adda-(D)-iso-Glu- $N$-methyldehydro-Ala-). The amino acid residues are numbered sequentially from (D)-alanine (1) to $N$-methyldehydroalanine (7), while the letters $\mathrm{X}$ and $\mathrm{Y}$ represent variable positions that are occupied by natural L-amino acids in the molecule (Figure 2) [17-19].

Figure 2. Structures of the most common isolated MCs and nodularins.

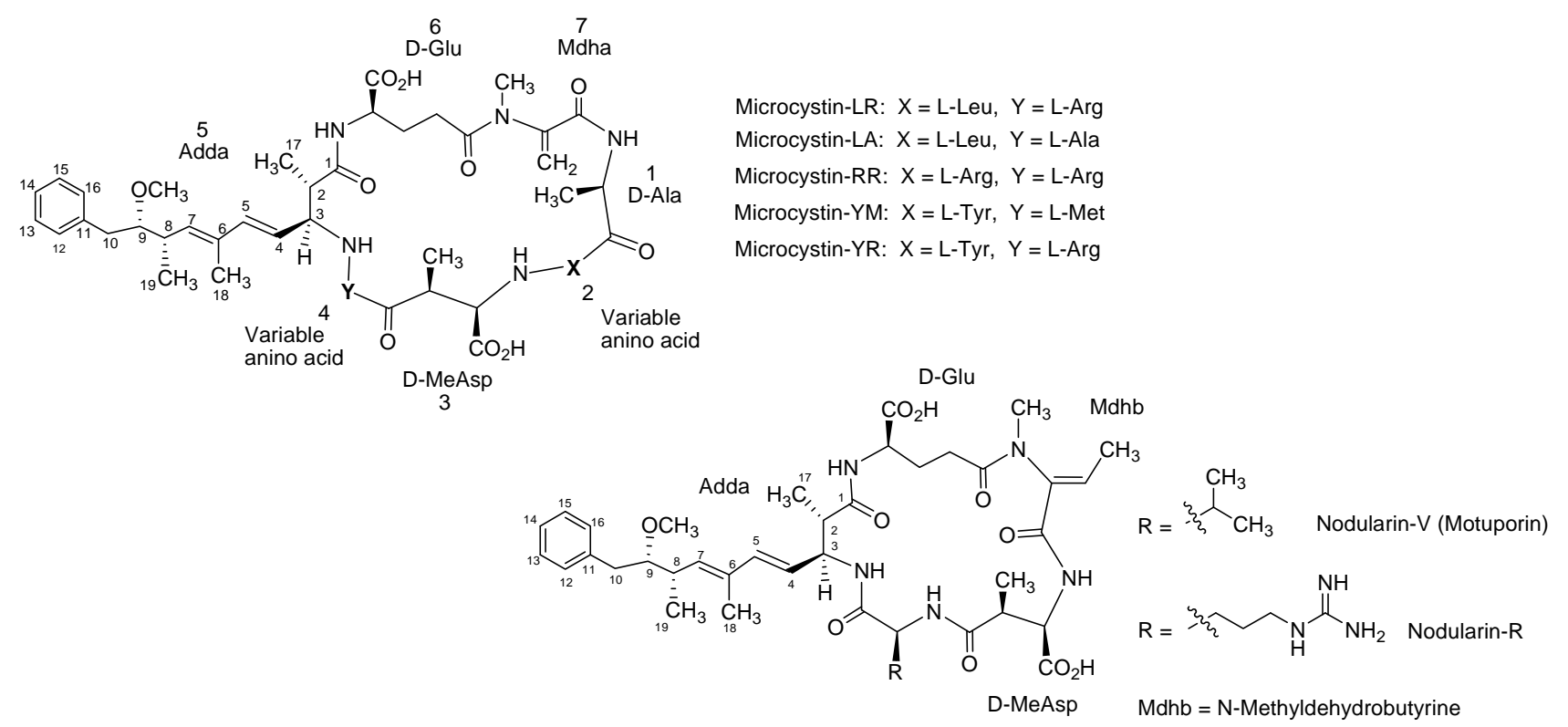

Among MC variants, the most toxic and common is MC-LR, in which the two variable amino acids are leucine and arginine [20]. The presence of the amino acid, Adda ([2S,3S,8S,9S]-3-amino-9- 
methoxy-2,6,8-trimethyl-10-phenyldeca-4,6-dienoic acid), is an unusual and specific structural feature of MCs [21]. Adda plays an important role in the biological activity of MC since as hydrogenation or ozonolysis of the diene system in this unit results in an inactive product [22,23]. Moreover, acylation of glutamate renders MCs less toxic or even nontoxic [24,25].

From a pharmacological standpoint MC-LR possesses several desirable properties such as water solubility and extreme stability in several exposure and handling conditions. Their stability in reservoir water is less than one week, but they are stable for longer periods of time in filtered or deionized water [26,27]. Moreover, MC-LR remains stable even after several hours of boiling, and it is also resistant to chemical hydrolysis or oxidation at near-neutral $\mathrm{pH}$ [28-30].

\subsection{Microcystin Biogenesis and Ecological Role and Function}

Microcystins are synthesized by a nonribosomal enzyme complex, as are most cyanobacterial peptides, encoded by the microcystin ( $m c y$ ) gene cluster. Mcy spans $\sim 55 \mathrm{~kb}$ and includes genes for peptide synthetases, polyketide synthases, mixed peptide synthetases and tailoring enzymes [31]. Their ecological role and function is currently unresolved although it is clear they have numerous effects on phytoplankton and zooplankton [32,33]. It has been proposed that MCs have evolved to function as a defense mechanism of cyanobacteria against grazing, a theory that has been debated by recent findings indicating that microcystin synthetase predated the metazoan lineage [34,35]. Other investigators have also found that MC is produced in response to extracellular metabolites released by herbivorous zooplankton [36,37] and that they may scavenge environmental metals, such as iron [38].

\subsection{Biological Activity of Microcystins as Xenobiotics}

\subsubsection{In Animals}

\subsubsection{Acute Exposure}

The first report of lethal intoxication of animals that drank water with a high burden of algal blooms was reported in Australia 140 years ago [4]. It later became clear that acute exposure to MCs can cause severe hepatocellular damage in animals and thus MCs were named hepatotoxins [39,40]. Considerable variation among animals is observed with regard to MC toxic sensitivity [41]. In mice the oral lethal dose that kills $50 \%$ of subjects (LD50) for MC-LR ranges from 5 to $10 \mathrm{mg} / \mathrm{Kg}$ bodyweight (bw), compared to $0.1 \mathrm{mg} / \mathrm{kg}$ bw in rats [42,43]. The intraperitoneal LD50 of MC-LR in mice and rats also varies, but a value of $50-100 \mu \mathrm{g} / \mathrm{gr}$ bw is commonly accepted [11,44]. With regard to other MCs the i.p LD50 for MC-LA, -YR, -YM are similar to that of MC-LR, but the i.p LD50 for MC-RR is ten times higher than that of MC-LR [5].

\subsubsection{Low-dose Chronic Exposure}

Chronic exposure of experimental animals to sub-lethal low doses of MC has been shown to promote tumorigenesis in coordination with dysfunctional p53 [45]. Moreover, in two-stage carcinogenicity assays, chronic MC exposure was shown to promote liver tumorigenesis once initiation 
occurred with known carcinogens diethylnitrosamine [46] azoxymethane [47] and particularly with aflatoxin B1 [48,49].

\subsubsection{In Humans}

\subsubsection{Acute Exposure}

The potential of $\mathrm{MC}$ to induce lethal toxicity in humans was recently recognized following a biological accident at a dialysis center in Caruaru, Brazil in 1996. A total of 100 out of 131 hemodialysis patients developed acute liver failure, and 76 died following accidental intravenous exposure to MC that had contaminated the dialysis water source (a municipal water supply). It was estimated that $19.5 \mu \mathrm{g} / \mathrm{L} \mathrm{MC}$ was in the water used for dialysis and the concentration of MC found in liver tissue from patients who died ranged from 0.03 to $0.60 \mathrm{mg}$ per kilogram of liver tissue (median, 0.18) [50-52]. Another minor incident of MC exposure in hemodialysis patients was also reported a few years later in Rio de Janeiro, Brazil. In this case, serum MC concentrations in patients ranged from $<0.16$ to $0.96 \mathrm{ng} / \mathrm{mL}$, and no fatalities occurred [53].

\subsubsection{Low-dose Chronic Exposure}

Data on chronic low-dose exposure to MCs are limited and mainly originate from epidemiological studies. A correlation between the high incidence of primary liver cancer and drinking water contaminated with MC during the summer time was first observed in certain provinces in China [54]. Similarly, an increased incidence of primary liver cancer was recorded during the last decade in certain Serbian regions in which the citizens made use of blooming water reservoirs for drinking purposes [55]. These epidemiology data, supported by in vivo studies, indicate that a combined exposure to hepatocarcinogen aflatoxin B1, hepatitis B virus and an intermittent intake of MCs may drive liver carcinogenesis [49,54]. In response to these observations and studies on MC toxicity, the WHO issued a provisional guideline for drinking water and set $1 \mu \mathrm{g} / \mathrm{L} \mathrm{MC}$-LR concentration as the upper cut-off safe level for drinking water [11,56].

\section{MC-LR Cell Molecular Targets}

The hydrophilic structure of most MC variants hinders their penetration through plasma cell membranes and therefore cell uptake is facilitated by a transporting system. Such transporters dedicated to handle intracellular transport of cyclic peptides are the organic anion transporting polypeptides (OATP) [57,58]. Currently, there is limited data on the transport of the various MC analogues by different members of the OATP family. According to our knowledge, MC variants and especially the most studied MC-LR has been identified as substrate for OATP1A2, OATP1B1 and OATP1B3 [58]. In mammals consuming water or food contaminated with MCs, the toxins are transported through the small intestine to the bloodstream via OATP-expressing epithelial cells that line the small intestine. Via the bloodstream, MCs finally concentrate in hepatocytes, which overexpress OATP. The hepatocellular toxic effects are generally attributed to disruption of reversible protein phosphorylation dynamics though inhibition of protein phosphatases (PP) type 1 and type 2A and the uncontrolled generation of high levels of ROS [59-62] (Figure 3). 
It has been reported that MC-LR covalently binds to cysteine residues of PP1 and PP2A [63]. As a result, inhibition of PP1 and PP2A leads to hyperphosphorylation of functional and cytoskeletal proteins and finally to cell apoptosis [39,64]. Macroscopically, the liver becomes swollen and hemorrhagic and the dissociation and disruption of the liver epithelium is extensive [65-67]. It is interesting that MC-RR, while an equally potent inhibitor of PP as MC-LR, requires higher concentrations to induce both hepatocyte deformation and increased protein phosphorylation. The reduced hepatotoxicity of MC-RR likely reflects a reduced affinity for the transporter [68]. In chronic low-dose exposure, MCs are also thought to exert tumor-promoting effects through inhibition of PP1 and PP2A, which are known to function as tumor suppressors [69]. PP inhibition leads in a shift in the balance between phosphorylation/dephosphorylation towards a higher phosphorylation status of target genes. For instance, PP2A has been shown to regulate the activity of at least 50 protein kinases, and thus the effect of a potent inhibitor of PP2A activity is likely to be detrimental to the cell. Protein kinase $\mathrm{C}(\mathrm{PKC})$, Akt, extracellular signal-regulate kinase (ERK), mitogen-activated protein kinase (MAPK), IкB kinase, p38 and caspase-3 are some of the proteins regulated by PP2A [46,70-72].

Figure 3. Cancer cell molecular targets and actions of cyanobacterial cyclopeptides. $(\mathrm{MC}=$ microcystin, $\mathrm{NOD}=$ nodularin, $\mathrm{OATP}=$ Organic Anion Transporting Polypeptides, $\mathrm{PP}=$ protein phosphatase, $\mathrm{MPT}=$ Mitochondrial permeability transition, $\mathrm{ROS}=$ reactive oxygen species, $\mathrm{GSH}=$ glutathione, CYP2E1 $=$ Cytochrome P450 2E1, red cross symbol $=$ inhibition, green cross symbol = consumption, black lines symbolize established action, grey lines symbolize likely actions).

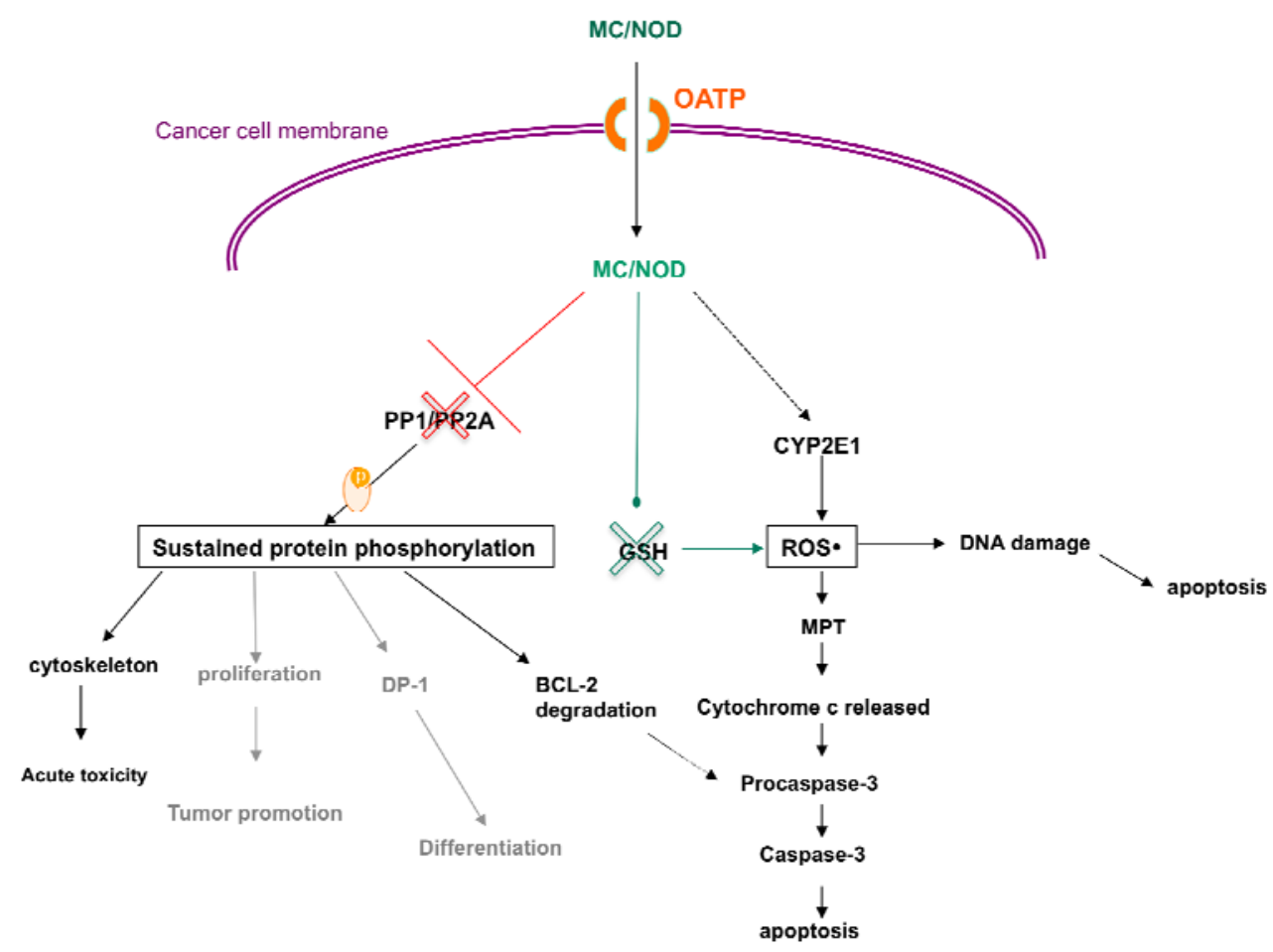

MC has also been shown to exert genotoxic effects such as DNA fragmentation, chromosomal aberrations, micronuclei formation, loss of heterozygosity and even base substitution 
mutations [10,73-75]. ROS are known to damage DNA. In this context, cyanobacterial cyclopeptides have been reported to produce free radicals and alter intracellular reduced glutathione (GSH) [76,77]. Moreover, i.p. treatment of mice with nodularin decreased the enzymatic activity of superoxide dismutase, catalase, and glutathione peroxidase [78].

Microcystins can also affect intracellular targets other than PP2A. For instance, the $h$ subunit of ATP-synthase was shown to be a MC binding protein and thus a possible target in liver cells [79]. Another potential target of MC could be mitochondrial aldehyde dehydrogenase II, which has been recently identified as a MC target in the human liver [80]. Given the important role of aldehyde dehydrogenase II in acetaldehyde detoxification and the prevention of free radical formation, the physical association of this enzyme with MC may, to some extent, explain the hepatotoxicity of MCs.

\section{Cytotoxic Effects of MC-LR}

\subsection{Activity of MC in Normal Cell Lines and Tissues}

In primary cultured rat hepatocytes treated with MC-LR for 24 and $72 \mathrm{~h}, \mathrm{LC} 50$ values were found to be $48 \mathrm{ng} / \mathrm{mL}$ and $8 \mathrm{ng} / \mathrm{mL}$, respectively. Exposure of rat hepatocytes to sub-lethal concentrations of MC-LR of 2 or $10 \mathrm{ng} / \mathrm{mL}$ for 3, 24 or $48 \mathrm{~h}$ results in the formation of ROS as demonstrated by an acute increase in intracellular reduced glutathione [16]. Extracts containing high concentrations of MC (675-2700 nM MC-LR eq.) caused apoptotic effects in rat hepatocytes and human lymphocytes. In rat hepatocytes morphological apoptotic changes were first observed after 30 min of incubation, but characteristic biochemical changes were not seen. In human lymphocytes, apoptotic morphological changes were seen $24 \mathrm{~h}$ after incubation. An incubation period of $48 \mathrm{~h}$ was judged optimal for the appearance of internucleosomal DNA degradation [81]. ROS were found to play a critical role in the mitochondrial permeability transition (MPT) after treatment of rat hepatocytes with MC-LR [82].

Ultra-rapid apoptosis was observed in primary hepatocytes following microinjection with both MC-LR and nodularin, characterized by cytoplasmic shrinkage, chromatin condensation, membrane blebbing, and procaspase-3 cleavage [83]. The finding that PP2A regulates BCL-2 phosphorylation is obviously of major therapeutic importance. Lin et al. found PP2A inhibition results in proteasomemediated degradation of the hyperphosphorylated BCL-2 at the endoplasmic reticulum [84]. Moreover, pharmacologic inhibition or RNA interference knockout of PP2A caused proteasomic degradation of phosphorylated BCL-2 and sensitized the cells to various cell death stimuli [85]. Taken together, these findings imply that MC can promote apoptosis in cancer cells that overexpress BCL-2 via a PP2A inhibition approach. ROS generation and resultant DNA damage were associated with MC-induced toxicity in other non-malignant non-liver cells $[86,87]$.

\subsection{Activity of MC in Cancer Cells}

To consider MCs as targets to developing potent anticancer drugs, tumor cells should demonstrate selective sensitivity to MC. Unfortunately the investigation of anticancer effects of MCs in vitro has been difficult due to the down-regulation of transporters in most cancer cell lines. This lack of expression agreement between transformed and ortholog cell lines and the corresponding tissue is a known problem with cell transporters attributed to down-regulation of transporter genes when cells are 
maintained in culture $[88,89]$. Characteristically, in freshly-isolated trout and murine hepatocytes a rapid loss of OATP transporter gene expression was observed and coincided with a loss of MC sensitivity in these cultured cells [90].

On the contrary, there is clear evidence that OATP are over-expressed in cancer tissues (detailed data are presented in the following section) [91]. Characteristically, OATP1B1 and OATP1B3 expression assessed by western blot assay was found in hepatocellular carcinoma [92]. In addition, OATP1B1 and OATP1B3 expression was detected in a few cell lines originating from liver, colon, and pancreatic tumors [93].

Zegura et al. have found that MC-LR induced DNA damage in HepG2 hepatoma cells related to decreased intracellular glutathione [77]. In another study, they observed a significantly increased ratio of expression of bax to bcl-2 induced by MC-LR, which suggests that apoptosis in HepG2 cells proceeds via the mitochondrial pathway [73]. Moreover, Monks at el., following observations that OATP1B3 mRNA is up-regulated in non-small cell lung cancer, transfected HeLa cervical cancer cells with the drug transporters OATP1B1 and OATP1B3 to create in vitro models in which MCs could gain intracellular access and test the activity of MCs against OATP-expressing cancer cells. Transfected HeLa cells were found to be 1,000-fold more sensitive to MC-LR than the vectortransfected control cells, showing that transporter expression imparts marked selectivity for $\mathrm{MC}$ cytotoxicity [12]. This finding suggests that MC cytotoxicity in OATP1B1- and OATP1B3-expressing HeLa cells is related to cell-specific inhibition of PP2A and not to PP inhibition in general.

\section{Organic Anion Transporting Polypeptides}

According to the Human Genome Organisation Gene Nomenclature Committee (http://www.genenames.org) the SLCO acronym is used for naming genes and OATP for the corresponding protein product of each gene. The gene official symbol SLCO stands for Solute Carrier Organic anion transporter family. The superfamily of OATP is further divided into families and subfamilies according to their amino acid sequence identity, $\geq 40 \%$ and $\geq 60 \%$, respectively. The OATP families include six members that are symbolized by OATP1, OATP2, OATP3, OATP4, OATP5 and OATP6. Next to the Arabic numeric system, which signifies the OATP family, a Latin letter is used to specify the subfamily type, i.e., OATP1A. Further classification of each subfamily member is achieved with an Arabic number next to the subfamily letter that corresponds to the order of discovery of the gene/product of each member.

\subsection{OATP Substrates}

Apart from MCs, numerous other endo- and xenobiotics with diverse chemical structures have been identified as substrates for members of the OATP family. Among them are hormones (mainly steroid and thyroid hormones), eicosanoids, bilirubin, bile acids, and drugs such as HMG-CoA-reductase inhibitors (holesterol lowering statins), digoxin, angiotensin-II receptor antagonists like olmesartan, antibiotics like levofloxacin and anticancer agents like methotrexate and taxanes. Each OATP subtype presents different substrate specificities. A comprehensive review of endogenous and xenobiotic substrates for human OATP family members, was recently published by König et al. [94]. 


\subsection{OATP Expression in Normal Human Tissues}

Depending on the family and subfamily type, some OATP members (Table 1) show a very specific profile of expression, i.e., $1 \mathrm{~B} 1$ and $1 \mathrm{~B} 3$ are both found in the liver $[58,92,95,96]$ and mononuclear cells [96], while expression of SLCO1B3 mRNA was detected in the cervix [96]. OATP6A1, also known as the gonad-specific anion transporter, is mainly identified in the testis [97,98], but also in the spleen, brain, fetal brain and the placenta [98] (Table 1).

Other OATP members show a less specific expression profile. OATP1A2 is found in the liver [95,99-101], the brain [58,95,96,100,102,103], the kidney [104], the eye [100], the prostate [95], and the mammary gland [105]. OATP1C1 is mainly located in the brain, testis, heart, eye and mammary gland $[96,100,103,105]$. OATP4C1 is identified in the kidney [103,106], and also in the lungs, skin, white blood cells (neutrophils, mononuclear cells and peripheral leukocytes), mammary gland and liver [96,107]. OATP5A1 is identified mainly in the prostate, skeletal muscles, thymus [96], on classically activated macrophages [108], and breast [107]. Other OATP members such as 2A1, 2B1, $3 \mathrm{~A} 1$ and $4 \mathrm{~A} 1$ are distributed ubiquitously throughout the human body [96,103,109-115]. Hence the brain and the liver appear to be the tissues with the most prominent OATP expression, along with the testes, breasts and kidneys.

Table 1. SLCO expression at the protein $(\mathrm{P})$ and mRNA $(\mathrm{m})$ level in normal and cancerous human tissues. Each color represents a different gene family.

\begin{tabular}{|c|c|c|}
\hline $\begin{array}{l}\text { Approved } \\
\text { gene symbol }\end{array}$ & Expression in human normal tissue & Expression in human tumor tissue \\
\hline SLCO1A2 & $\begin{array}{l}\text { Liver }(\mathrm{m} ; \mathrm{P}), \text { Brain }(\mathrm{m}) \text {, blood barrier }(\mathrm{P}), \operatorname{Kidney}(\mathrm{m} ; \mathrm{P}), \\
\text { Testis }(\mathrm{m}), \text { Prostate }(\mathrm{m}) \text {, Breast }(\mathrm{m}) \text {, Retina }(\mathrm{m})\end{array}$ & Glioma (m;P); Bone tumors (m) \\
\hline$S L C O 1 B 1$ & Liver (m; P), Mononuclear cells (m) & HCC (m; P); Colorectal Cancer (m) \\
\hline$S L C O 1 B 3$ & Liver (m; P), Cervix (m), Mononuclear cells (m) & $\begin{array}{l}\text { Colon Cancer (m; P); Breast cancer (P); Non } \\
\text { Small Cell Lung Cancer (m); HCC (m; P) }\end{array}$ \\
\hline SLCO1C1 & Brain (m); Testis (m; P), Heart (m), Retina (m), Breast (m) & Glioma (m); Bone tumors (m) \\
\hline$S L C O 2 A 1$ & Ubiquitous (protein detected only in GI tract tissue) & $\begin{array}{l}\text { Colon cancer }(\mathrm{m}) \text {; Lung cancer }(\mathrm{m}) \text {; Bone } \\
\text { tumor }(\mathrm{m}) \text {, Breast cancer }(\mathrm{m})\end{array}$ \\
\hline$S L C O 2 B 1$ & Ubiquitous (protein detected only in liver tissue) & $\begin{array}{l}\text { Glioma }(\mathrm{m} ; \mathrm{P}) \text {; Colon cancer }(\mathrm{m}) \text {; Lung cancer } \\
(\mathrm{m}) \text {; Bone tumors }(\mathrm{m}) \text {; Breast cancer }(\mathrm{m})\end{array}$ \\
\hline$S L C O 3 A 1$ & $\begin{array}{l}\text { Ubiquitous and also in Peripheral Blood Mononuclear Cells } \\
\text { (PBMC) (data available only on mRNA level) }\end{array}$ & $\begin{array}{l}\text { Lung cancer }(\mathrm{m}) \text {; Colon cancer }(\mathrm{m}) \text {; Bone } \\
\text { tumors }(\mathrm{m}) \text {; Breast cancer }(\mathrm{m})\end{array}$ \\
\hline$S L C O 4 A 1$ & $\begin{array}{l}\text { Ubiquitous (protein detected only in brain and placenta } \\
\text { tissues) }\end{array}$ & $\begin{array}{l}\text { Glioma }(\mathrm{m}) \text {; Lung cancer }(\mathrm{m}) \text {; colon cancer } \\
(\mathrm{m}), \text { Bone tumor }(\mathrm{m}) \text {; Breast cancer }(\mathrm{m})\end{array}$ \\
\hline$S L C O 4 C 1$ & 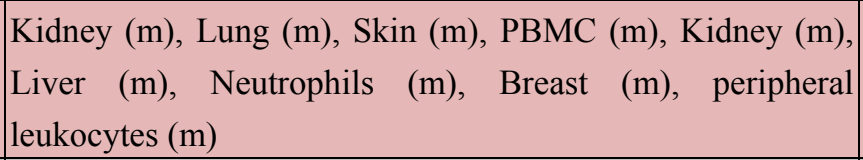 & $\begin{array}{l}\text { Lung cancer }(\mathrm{m}) \text {; Bone tumor }(\mathrm{m}) \text {; Breast } \\
\text { cancer }(\mathrm{m})\end{array}$ \\
\hline$S L C O 5 A 1$ & $\begin{array}{l}\text { Prostate }(\mathrm{m}) \text {, Skeletal muscles }(\mathrm{m}), \text { Thymus }(\mathrm{m}), \text { Classically } \\
\text { activated macrophages }(\mathrm{m}) \text {, Breast }(\mathrm{m}) \text {. }\end{array}$ & Bone tumors $(\mathrm{m})$; Breast cancer $(\mathrm{m})$ \\
\hline SLCO6A1 & $\begin{array}{l}\text { Testis }(\mathrm{m}) \text {, Spleen }(\mathrm{m}), \text { Brain }(\mathrm{m}) \text { (especially fetal brain), } \\
\text { Placenta }(\mathrm{m})\end{array}$ & 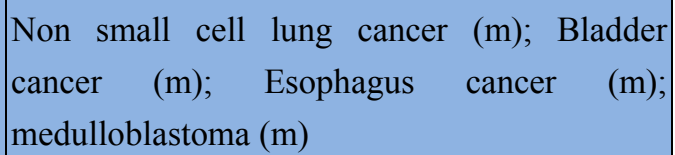 \\
\hline
\end{tabular}




\subsection{OATP Expression in Human Cancers}

OATP expression in cancers has been poorly investigated (Table 1). Nevertheless, among OATP members OATP1B1 and 1B3 were found expressed mainly in hepatocellular carcinoma $[92,116,117]$ with the second (1B3) also expressed in colon cancer [91], breast cancer [118], and non-small cell lung cancer [12]. OATP1A2, 1C1, 2B1 and 4A1 show an expression preference for gliomas [102] and primary or metastatic bone tumors [119]. In addition, OATP2B1 and 4A1 appear to also be expressed in breast, colon and lung cancers [107,119]. Similarly, OATP 2A1, 3A1, 4C1 and 5A1 show a common expression profile for breast cancer and bone tumors [107,119]. Furthermore, 2A1, 3A1 and 4C1 expression has been identified in lung cancer, and 2A1 and 3A1 in colon cancer [96,107]. The gonad-specific transporter OATP6A1 has shown a rather high-frequency expression in non-small cell lung cancer, bladder tumors, esophageal tumors and in medulloblastoma [98,120].

We consider that the mechanisms that modulate OATP expression in cancer tissues warrant rigorous investigation. Obviously more studies are needed to map OATP expression in human cancers as the target of an emerging novel class of targeted therapeutics for the treatment of refractory metastatic cancers.

\subsection{OATP: Cancer Trapdoors to Be Exploited}

Despite small incremental improvements achieved with the introduction of targeted cancer therapeutics in clinical practice, it is widely accepted that systemic therapy of several advanced common cancers has failed to meet hopeful expectations and unfortunately remains an unmet need [121-123]. It is now accepted that a kernel of refractory stem-like cancer cells turn these tumors into "hard to die" cancers $[124,125]$. To address this therapeutic limitation, oncological research has shifted its focus to individualized therapeutic approaches with the aim of maximizing treatment benefits [126]. However, novel therapeutic strategies, more specific targets and innovative therapies are desperately needed to improve therapeutic options [127,128]. In this area, the influx membrane transporters of selective substrates appear to be an overlooked option, although they have been clinically proven to be a valid therapeutic target $[129,130]$.

With regard to MC, the low growth inhibition activity of MC-LR (GI50 $>5 \mu \mathrm{M}$ at $24 \mathrm{~h}$ ) in cancer cell lines [131] due to its low cell permeability in the absence of specific transporters, in conjunction with the moderate selectivity profile for PP1 and PP2A inhibition, has led the scientific community to overlook their therapeutic potential for years [132]. Interest is now revived following elucidation of knowledge on cell influx transporters of MC.

However, to achieve a clinically meaningful therapeutic window for MC-derived therapeutics, the issue of anticipated hepatic toxicity of these agents needs to be addressed. It is promising that in OATP-transfected HeLa cells, MC induced cytotoxic effects at concentrations in the subnanomolar range, significantly lower than the doses required for hepatic toxicity in experimental animals [12]. This finding suggests that normal hepatocytes may differ from cancer cells in sensitivity to MC for metabolic reasons.

Such metabolic differences between normal and malignant cells in the context of MC activity have been explored. Microcystin and the related toxic cyclic peptide nodularin are shown to stimulate 
glutathione-dependent detoxification pathways in normal hepatocytes. Exposure of rat hepatocytes to sub-lethal concentrations of MC-LR resulted in an acute increase in intracellular glutathione in parallel with increased ROS [16]. Addition of $\mathrm{N}$-acetylcysteine (NAC) to the culture medium, an agent that increases intracellular glutathione concentrations, decreased sensitivity of cultured rat hepatocytes to MC. Conversely, cultured hepatocytes treated with buthionine sulfoximine, an agent that decreases intracellular glutathione, became increasingly sensitive to cyanobacterial extract [82]. These studies suggest that glutathione plays a role in the in vivo hepatic detoxification of MCs. In contrast, in the HeLa cell model neither NAC nor buthionine sulfoximine affected MC toxicity, indicating that there are metabolic differences in MC intracellular targets between hepatocytes and cancer cells [12]. Finally, based on the tissue distribution, excretion and hepatic biotransformation of MC-LR, toxicity is considered to be related to long-term cellular retention, presumably through covalent binding of the toxin or its metabolites with high molecular weight components [133].

\section{MC Analogues: Potentials and Perspectives}

It has been suggested that developing MC-LR structural analogs of higher cancer specificity and selected for a broader therapeutic index may efficiently target OATP-expressing tumors [134]. This perspective is well served by the chemical structure of these natural cytotoxins as shown below.

\subsection{Combinatorial Chemical Synthesis}

\subsubsection{The Adda Issue}

SAR data revealed that the Adda and D-glutamic acid regions play highly important roles in the hepatotoxicity of MCs, providing a steric configuration that is directly involved both in the carrier protein, conveying cell specificity as well as at the active site of protein phosphatase [135]. The crystal structure of mammalian PP1 complexed with MC-LR confirmed the major aspects of the conserved acid binding domain pharmacophore model [136]. The glutamic acid carboxyl group and the Adda carbonyl group bind to the metal-binding site via metal-liganded water. In addition, the MeAsp carboxyl group hydrogen binds to Arg 96 and Tyr 134. The long hydrophobic tail of Adda is placed in the hydrophobic groove region of PP1, adjacent to the active site, while the L-arginine side chain is fully exposed to the solvent and does not form any significant contacts with PP1 or PP2A. The carbon of the $N$-methyldehydroalanine side-chain is covalently linked to the Cys 273 of PP1, a linkage that is secondary to the inhibition activity of the toxin and likely occurs as a delayed reaction in solution [136,137]. However, the biological relevance of this reaction is unknown. Although they share similar biological properties, MCs and nodularins have important functional differences with respect to their interaction with PP1 and PP2A. Although both toxins initially bind non-covalently and inhibit these enzymes, crystallographic data shows that nodularins, including motuporin, do not bind covalently to PP1 or PP2A even as a delayed reaction [138]. This fact is despite the presence of an $\mathrm{N}$-methyldehydrobutyrine (NMdhb) residue that could undergo a Michael addition reaction with Cys 273, similar to the reaction of the Nmdha residue in MC-LR.

Due to their unique biological properties, MCs and nodularins have been the target of synthetic organic chemists in the pursuit of a total synthesis that can provide access to a series of structurally 
modified analogues. This work resulted in the total synthesis of MC-LA (MC-LA) [139]. In an effort to design compounds with increased PP1 selectivity, Chamberlin synthesized new MC-LA variants (Table 2) inspired by his total synthesis of MC-LA [139]. Replacement of the L-leucine residue with cyclohexylalanine led to a variant of MC-LA with a seven-fold increased selectivity for PP1 and high potency $(0.52 \mathrm{~nm})$ [140]. Despite its high potency and the best selectivity profile reported to date, the low cell-permeability of this cyclic inhibitor would limit its further development. Also, a series of greatly simplified analogues comprised only of Adda, and of a single additional amino acid, or of synthetic linearized and truncated peptides, were prepared, a few of which retained moderate activity as PP1/PP2A inhibitors [141]. On the contrary, linear analogs of microcystins MC-RR, MC-YM, MCLA in which the Adda region was neither incorporated nor replaced by another hydrophobic residue were inactive, and did not reveal any signs of toxicity in white mice [142,143]. Moreover, an Addabased compound, a mimic of the RVXF peptides, was found to bind at the PP1 regulatory site and activate the enzyme, in direct contrast to its strongly inhibiting progenitor MC-LR [144].

Table 2. Comparison of IC50 (nM) values of synthetic MC-LA and variants in relation to the purified catalytic subunits of PP1 and PP2A.

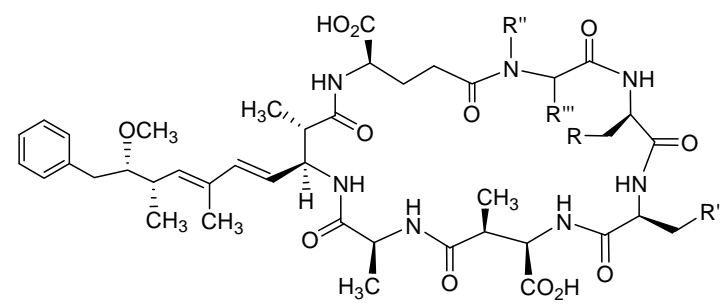

\begin{tabular}{|c|c|c|c|c|c|c|c|}
\hline \multirow[b]{2}{*}{ Inhibitor } & \multirow[b]{2}{*}{$\mathbf{R}$} & \multirow[b]{2}{*}{$\mathbf{R}^{\prime}$} & \multirow[b]{2}{*}{$\mathbf{R}^{\prime \prime}$} & \multirow[b]{2}{*}{$\mathbf{R}^{\prime \prime}$} & \multicolumn{2}{|c|}{ Inhibition $\left(\mathrm{IC}_{50} \mathrm{~nm}\right)$} & \multirow[b]{2}{*}{ PP1 selectivity } \\
\hline & & & & & PP1c & PP2Ac & \\
\hline MC-LA (synthetic) & $\mathrm{H}$ & $\mathrm{CH}\left(\mathrm{CH}_{3}\right)_{2}$ & $\mathrm{CH}_{3}$ & $=\mathrm{CH}_{2}$ & 0.3 & 0.3 & 1 \\
\hline 1 & $\mathrm{H}$ & Cyclohexyl & $\mathrm{CH}_{3}$ & $\mathrm{CH}_{2}$ & 0.52 & 3.4 & 7 \\
\hline 2 & $\mathrm{H}$ & $i$-Propyl & Cyclohexyl & $\mathrm{H}$ & 0.8 & 1.5 & 2 \\
\hline 3 & $\mathrm{H}$ & $i$-Propyl & $\mathrm{CH}_{3}$ & $\mathrm{H}$ & 0.8 & 1.5 & 2 \\
\hline 4 & $\mathrm{NH}_{3}{ }^{+}$ & $i$-Propyl & $\mathrm{CH}_{3}$ & $\mathrm{CH}_{2}$ & 3 & 9 & 3 \\
\hline
\end{tabular}

\subsubsection{Synthetic Approaches}

We are in the process of harnessing the power of synthetic organic chemistry to attenuate the toxicity of MCs by designing structural variants with an improved therapeutic profile. Entry to such $\mathrm{MC}$ analogues can be achieved by a) the direct chemical elaboration of the MC scaffold exploiting the dense array of functional groups and/or b) the de novo design and synthesis of new MC variants exploiting the synthetic strategies developed for the total synthesis of MCs.

Although the direct elaboration of the MC scaffold can offer immediate access to new analogues, its scope may be limited as the modification of the readily accessible functional groups (i.e., Adda, D-Glu) may lead to compounds with a complete loss of cytotoxicity. Conjugate addition of glutathione (GSH) and cysteine (Cys) to $\mathrm{N}$-methyldehydroalanine in MCs resulted in adducts with reduced toxicity, as seen upon assessing LD50 values using mice [145]. Considering that $N$-methyldehydroalanine may be responsible for the long-term hepatic retention and the toxicity of MCs, conjugate addition of a wide 
range of oxygen, nitrogen and sulfur based nucleophiles to the $N$-methyldehydroalanine double bond could give access to new MC analogs with reduced hepatic toxicity (Figure 4).

Figure 4. Conjugate addition of a wide range of nucleophiles to MC-LR.

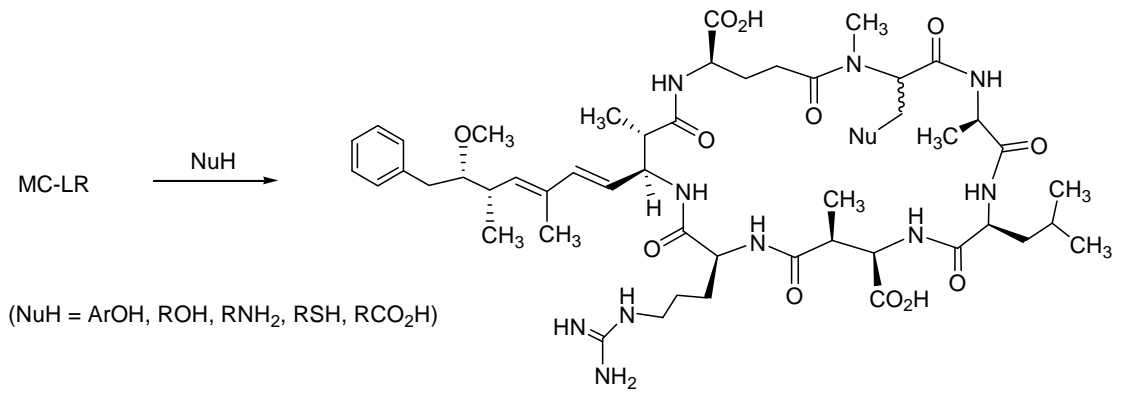

This strategy would quickly clarify whether the dehydroalanine moiety is implicated in the longterm hepatic retention and the acute toxicity of the MC-LR. However, the limited availability of these toxins may hinder the scope of this strategy. Therefore, access to a series of structurally diverse new $\mathrm{MC}$ analogues with the desired pharmacological profile requires a combinatorial approach. We are currently in the process of preparing analogs with a wide range of diversity elements by solution or solid-phase strategies through the coupling of fragments I-III to tetrapeptide IV, which could in turn cyclize to MC variants with a general structure V (Figure 5).

Figure 5. A combinatorial approach to structurally diverse microcystins.

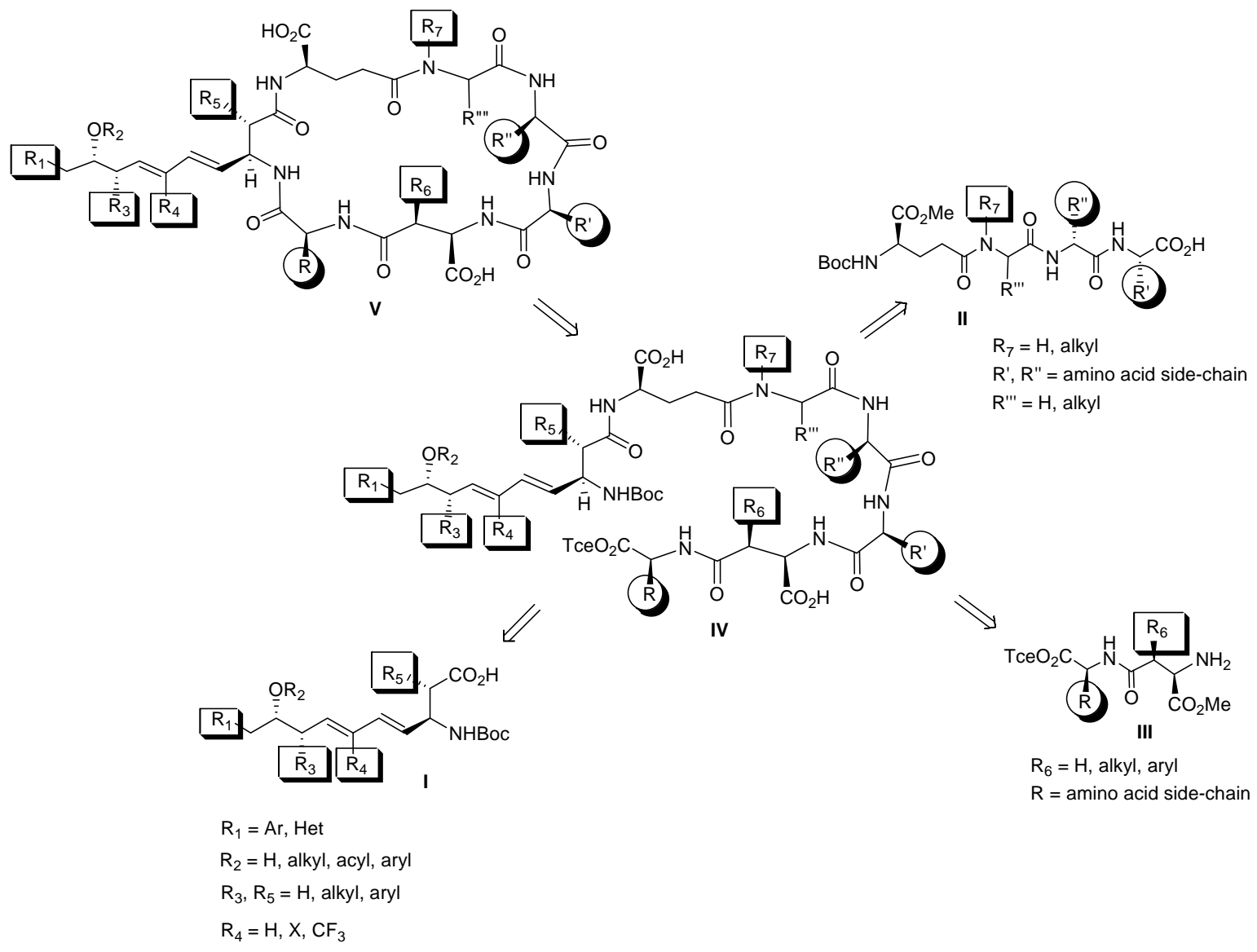




\subsection{Combinatorial Total Biosynthesis}

Their macrocyclic ring enables MCs to adopt a high degree of structural pre-organization in such a way that critical functional groups can interact with their protein partners without any major entropic loss upon binding [136,146-149]. This pre-organized ring structure can lead to high affinity and selectivity for protein targets, preserving at the same time appropriate bioavailability. Despite the therapeutic potential of these compounds and the fact that more than 100 marketed macrocyclic drugs have been derived from natural products, cyanobacterial cyclopeptides have been ill-exploited for the discovery of novel anticancer compounds [132]. This under-exploration is due to challenges imposed by their structural complexity in their chemical synthesis during the lead optimization process. Therefore, novel strategies are required to effectively screen the sub-portion of the biologically active chemical space that could be sampled by novel MC analogues.

Microcystin biosynthesis is accomplished on large $(55-\mathrm{kb})$ non-ribosomal peptide synthetase gene clusters (NRPS) [150,151] that include mixed peptide synthetases polyketide synthases, peptide synthetases, tailoring enzymes, and polyketide synthases [151-154]. Numerous toxins, siderophores and antimicrobial compounds are synthesized in NRPS enzyme complexes $[155,156]$. Interestingly, more than 70 structural variants of MCs can be synthesized from these enzyme complexes with modifications in the amino acid or the peptide backbone [157,158]. This wide variety of MC analogues raises two critical questions: why and how can Nature perform this efficient combinatorial chemistry via NRPS? A potential rationalization for the requisiteness of such chemical variability could be ascribed to the necessity of the MC-producing microorganisms to provide diverse chemical signals to decode complex modes of microbial interactions or for defense purposes against other organisms.

NRPS are organized in modular assembly lines in which each module, made of conserved catalytic domains, incorporates a given monomer unit into the growing chain for the biosynthesis of complex MCs. Each domain within these modules can be responsible for the adenylation, thioester formation, condensation of specific amino acids, amino acid modification (i.e., oxidation, heterocyclization, formylation, epimerization) $[155,156,159]$. The pattern in which these catalytic domains are assembled within the multifunctional enzymes determines the order and the number of the residues to be incorporated in the final product [156]. Thus, recombination within this assembly line is one of the main mechanisms determining the diversification of NRPSs [158]. A recent study focusing on the microcystin synthetase gene cluster [160] has demonstrated that functional peptide synthetases are created in nature through the transfer of adenylation domains without the concomitant transfer of condensation domains. Currently, there is heightened interest in engineering non-ribosomal peptide synthetases toward the creation of novel bioactive peptides [156]. Engineering single amino acid changes in the putative substrate binding sites of adenylation domains of the NRPS gene clusters could provide synthetic diversification by tuning the type of amino acid that is recognized and activated by the adenylation domain [161,162]. Another way that the NRPS could be tailored to allow the biosynthesis of novel MC peptides is the construction of chimeric enzymes where single domains or intact modules are exchanged [163]. To achieve efficient reengineering of this assembly line towards the design of new bioactive molecules with improved therapeutic properties, prior knowledge of the module or domain structure and interactions is of critical importance [164-168]. Reconstitution of native and engineered biosynthetic pathways for MCs in model heterologous hosts (Escherichia coli 
and Saccharomyces cerevisiae) could provide an efficient way to surmount complex problems associated with total chemical synthesis [169-171]. Such combinatorial total biosynthesis using heterologous expression systems could accelerate the exploration of biosynthetic potential of microorganisms and enable the construction of an economical and efficient platform for mass production of MC analogues. The very recent constructive efforts are starting to shed light on an understanding of the architecture of the enzymatic assembly lines for MC production that have evolved over millions of years. This understanding at the biosynthetic level, and in synergy with chemistry, could greatly contribute to the increasing structural diversity of MCs and open new avenues for the rational design of novel $\mathrm{MC}$ analogues with improved cancer therapeutic properties.

\subsection{Selectivity and Function}

Cancer selectivity is essential for candidate compounds to be developed into successful anticancer drugs. We presume that a degree of selectivity might be achieved for MC analogues through lead optimization strategies that are directed towards the development of $\mathrm{MC}$-antidote conjugates. We also consider that using approaches that target exploiting genetic and metabolic differences between cancer and normal cells can help develop cancer selective MC analogues.

Currently we are working on the conjugation of the ROS-scavenging agent $N$-Acetylcysteine (NAC) to microcystin-LR via its sulfhydryl unit on the intent to develop microcystin-NAC conjugates, which could preferentially damage OATP expressing cancer cells and spare healthy tissues. This strategy is supported by data showing that NAC works differentially in healthy and cancerous tissues. Characteristically, animal and human studies have shown that normal liver cells exposed to various hepatotoxic agents including microcystin (animal studies) can be rescued by NAC if given early [172-175], which is not the case for cancer cells $[12,176]$.

A major biochemical feature of MC toxicity is the intracellular generation of reactive oxygen species (ROS) [40,177]. This biological effect could turn out to be a competitive advantage for MC analogues, when they are considered as potential cancer therapeutics, given that the elevation of intracellular ROS above a threshold level seem to constitute the biochemical basis of ROS-mediated cancer therapeutics [178]. It is worth noticing that cancer cells live in a state of increased basal oxidative stress, which makes them vulnerable to further ROS insults induced by exogenous agents [179-181] Therefore, microcystin analogues can selectively kill OATP expressing cancer cells without causing significant toxicity to normal cells, by exploiting the redox difference between normal and cancer cells. We consider that this approach may be improved by OATP inhibitors, as are rifampicin and cyclosporine-A, which at carefully selected dosing schedules could fine tune optimal redox modulation at target tissues $[182,183]$. Moreover, it is considered that MC analogues might even provide a possibility for radical therapeutic approach for cancer by disturbing the redox balance in OATP expressing cancer stem-like cells, which are thought to share features of normal stem cells and also exhibit malignant cell characteristics in redox regulation [178,184].

A third approach we are currently working on is scanning human solid tumors for SLCO mutations on the aim to develop MC analogues with selective affinity towards cancer-specific OATPs $[94,185,186]$. Finally throughout our drug development program we are using functional 
activity-based protein profiling approaches coupled with network pharmacology aiming to select the most potent analogues with minimal off-target in healthy tissues [187,188].

\section{Conclusions}

In the era of targeted cancer therapy, cyanotoxins comprise a rich source of natural cytotoxic compounds with a potential to target cancers expressing specific uptake transporters. Moreover, their structure offers opportunities for combinatorial engineering to enhance the therapeutic index and resolve organ-specific toxicity issues. Considering cyanobacterial cyclopeptides as potential novel targeted anticancer therapeutics, we focus on developing microcystin analogues optimized to efficiently target OATP-expressing metastatic cancers that are resistant to conventional chemotherapy.

\section{Acknowledgment}

This project was partly supported with a grant from the Prefecture of Ioannina, Greece.

\section{References and Notes}

1. Awramik, S.M. The oldest records of photosynthesis. Photosynth. Res. 1992, 33, 75-89.

2. Blank, C.E.; Sanchez-Baracaldo, P. Timing of morphological and ecological innovations in the cyanobacteria-a key to understanding the rise in atmospheric oxygen. Geobiology 2010, 8, 1-23.

3. Zehr, J.P.; Waterbury, J.B.; Turner, P.J.; Montoya, J.P.; Omoregie, E.; Steward, G.F.; Hansen, A.; Karl, D.M. Unicellular cyanobacteria fix N2 in the subtropical North Pacific Ocean. Nature 2001, 412, 635-638.

4. Francis, G. Poisonous Australian lake. Nature 1878, 18, 11-12.

5. Gupta, N.; Pant, S.C.; Vijayaraghavan, R.; Rao, P.V. Comparative toxicity evaluation of cyanobacterial cyclic peptide toxin microcystin variants (LR, RR, YR) in mice. Toxicology 2003, 188, 285-296.

6. Falconer, I.R.; Humpage, A.R. Health risk assessment of cyanobacterial (blue-green algal) toxins in drinking water. Int. J. Environ. Res. Public Health 2005, 2, 43-50.

7. Vareli, K.; Briasoulis, E.; Pilidis, G.; Sainis, I. Molecular confirmation of Planktothrix rubescens as the cause of intense, microcystin-Synthesizing cyanobacterial bloom in Lake Ziros, Greece. Harmful Algae 2009, 8, 447-453.

8. Vareli, K.; Pilidis, G.; Mavrogiorgou, M.C.; Briasoulis, E.; Sainis, I. Molecular characterization of cyanobacterial diversity and yearly fluctuations of Microcystin loads in a suburban Mediterranean Lake (Lake Pamvotis, Greece). J. Environ. Monit. 2009, 11, 1506-1512.

9. Sarnelle, O.; Morrison, J.; Kaul, R.; Horst, G.; Wandell, H.; Bednarz, R. Citizen monitoring: Testing hypotheses about the interactive influences of eutrophication and mussel invasion on a cyanobacterial toxin in lakes. Water Res. 2009, 44, 141-150.

10. Gaudin, J.; Le Hegarat, L.; Nesslany, F.; Marzin, D.; Fessard, V. In vivo genotoxic potential of microcystin-LR: a cyanobacterial toxin, investigated both by the unscheduled DNA synthesis (UDS) and the comet assays after intravenous administration. Environ. Toxicol. 2009, 24, 200-209. 
11. van Apeldoorn, M.E.; van Egmond, H.P.; Speijers, G.J.; Bakker, G.J. Toxins of cyanobacteria. Mol. Nutr. Food Res. 2007, 51, 7-60.

12. Monks, N.R.; Liu, S.; Xu, Y.; Yu, H.; Bendelow, A.S.; Moscow, J.A. Potent cytotoxicity of the phosphatase inhibitor microcystin LR and microcystin analogues in OATP1B1- and OATP1B3expressing HeLa cells. Mol. Cancer Ther. 2007, 6, 587-598.

13. Herfindal, L.; Kasprzykowski, F.; Schwede, F.; Lankiewicz, L.; Fladmark, K.E.; Lukomska, J.; Wahlsten, M.; Sivonen, K.; Grzonka, Z.; Jastorff, B.; Doskeland, S.O. Acyloxymethyl esterification of nodularin- $\mathrm{R}$ and microcystin-LA produces inactive protoxins that become reactivated and produce apoptosis inside intact cells. J. Med. Chem. 2009, 52, 5758-5762.

14. Carmichael, W.W. The toxins of cyanobacteria. Sci. Am. 1994, 270, 78-86.

15. Gulledgea, B.M.; Aggena, J.B.; Huangb, H.B.; Nairnc, A.C.; Chamberlin, A.R. The microcystins and nodularins: cyclic polypeptide inhibitors of PP1 and PP2A. Curr. Med. Chem. 2002, 9, 1991-2003.

16. Bouaicha, N.; Maatouk, I. Microcystin-LR and nodularin induce intracellular glutathione alteration, reactive oxygen species production and lipid peroxidation in primary cultured rat hepatocytes. Toxicol. Lett. 2004, 148, 53-63.

17. Lanaras, T.; Cook, C.M.; Eriksson, J.E.; Meriluoto, J.A.; Hotokka, M. Computer modelling of the 3-dimensional structures of the cyanobacterial hepatotoxins microcystin-LR and nodularin. Toxicon 1991, 29, 901-906.

18. Sivonen, K.; Carmichael, W.W.; Namikoshi, M.; Rinehart, K.L.; Dahlem, A.M.; Niemela, S.I. Isolation and characterization of hepatotoxic microcystin homologs from the filamentous freshwater cyanobacterium Nostoc sp. strain 152. Appl. Environ. Microbiol. 1990, 56, 2650-2657.

19. Namikoshi, M.; Rinehart, K.L.; Sakai, R.; Stotts, R.R.; Dahlem, A.M.; Beasley, V.R.; Carmichael, W.W.; Evans, W.R. Identification of 12 hepatotoxins from a Homer Lake bloom of the cyanobacteria Microcystis aeruginosa, Microcystis viridis, and Microcystis wesenbergii: nine new microcystins. J. Org. Chem. 1992, 57, 866-872.

20. de Figueiredo, D.R.; Azeiteiro, U.M.; Esteves, S.M.; Goncalves, F.J.; Pereira, M.J. Microcystinproducing blooms--a serious global public health issue. Ecotoxicol. Environ. Saf. 2004, 59, 151-163.

21. Harada, K.; Imanishi, S.; Kato, H.; Mizuno, M.; Ito, E.; Tsuji, K. Isolation of Adda from microcystin-LR by microbial degradation. Toxicon 2004, 44, 107-109.

22. Nishiwaki-Matsushima, R.; Nishiwaki, S.; Ohta, T.; Yoshizawa, S.; Suganuma, M.; Harada, K.; Watanabe, M.F.; Fujiki, H. Structure-function relationships of microcystins, liver tumor promoters, in interaction with protein phosphatase. Jpn. J. Cancer Res. 1991, 82, 993-996.

23. Bourne, D.G.; Jones, G.J.; Blakeley, R.L.; Jones, A.; Negri, A.P.; Riddles, P. Enzymatic pathway for the bacterial degradation of the cyanobacterial cyclic peptide toxin microcystin LR. Appl. Environ. Microbiol. 1996, 62, 4086-4094.

24. Harada, K.; Ogawa, K.; Matsuura, K.; Murata, H.; Suzuki, M.; Watanabe, M.F.; Itezono, Y.; Nakayama, N. Structural determination of geometrical isomers of microcystins LR and RR from cyanobacteria by two-dimensional NMR spectroscopic techniques. Chem. Res. Toxicol. 1990, 3, $473-481$. 
25. Tooming-Klunderud, A.; Rohrlack, T.; Shalchian-Tabrizi, K.; Kristensen, T.; Jakobsen, K.S. Structural analysis of a non-ribosomal halogenated cyclic peptide and its putative operon from Microcystis: implications for evolution of cyanopeptolins. Microbiology 2007, 153, 1382-1393.

26. Hyenstrand, P.; Rohrlack, T.; Beattie, K.A.; Metcalf, J.S.; Codd, G.A.; Christoffersen, K. Laboratory studies of dissolved radiolabelled microcystin-LR in lake water. Water Res. 2003, 37, 3299-3306.

27. Oliveira, A.C.; Magalhaes, V.F.; Soares, R.M.; Azevedo, S.M. Influence of drinking water composition on quantitation and biological activity of dissolved microcystin (cyanotoxin). Environ. Toxicol. 2005, 20, 126-130.

28. Tsuji, K.; Watanuki, T.; Kondo, F.; Watanabe, M.F.; Suzuki, S.; Nakazawa, H.; Suzuki, M.; Uchida, H.; Harada, K.I. Stability of microcystins from cyanobacteria--II. Effect of UV light on decomposition and isomerization. Toxicon 1995, 33, 1619-1631.

29. Akcaalan, R.; Young, F.M.; Metcalf, J.S.; Morrison, L.F.; Albay, M.; Codd, G.A. Microcystin analysis in single filaments of Planktothrix spp. in laboratory cultures and environmental blooms. Water Res. 2006, 40, 1583-1590.

30. Zhang, D.; Xie, P.; Chen, J. Effects of Temperature on the Stability of Microcystins in Muscle of Fish and Its Consequences for Food Safety. Bull. Environ. Contam. Toxicol. 2010, 84, 202-207.

31. Noguchi, T.; Shinohara, A.; Nishizawa, A.; Asayama, M.; Nakano, T.; Hasegawa, M.; Harada, K.; Nishizawa, T.; Shirai, M. Genetic analysis of the microcystin biosynthesis gene cluster in Microcystis strains from four bodies of eutrophic water in Japan. J. Gen. Appl. Microbiol. 2009, 55, 111-123.

32. Sedmak, B.; Elersek, T. Microcystins induce morphological and physiological changes in selected representative phytoplanktons. Microb. Ecol. 2006, 51, 508-515.

33. Hu, Z.Q.; Liu, Y.D.; Li, D.H. Physiological and biochemical analyses of microcystin-RR toxicity to the cyanobacterium Synechococcus elongatus. Environ. Toxicol. 2004, 19, 571-577.

34. DeMott, W.R.; Moxter, F. Foraging Cyanobacteria by Copepods: Responses to Chemical Defense and Resource Abundance. Ecology 1991, 72, 1820-1834.

35. Schatz, D.; Keren, Y.; Vardi, A.; Sukenik, A.; Carmeli, S.; Borner, T.; Dittmann, E.; Kaplan, A. Towards clarification of the biological role of microcystins, a family of cyanobacterial toxins. Environ. Microbiol. 2007, 9, 965-970.

36. Armitage, A.R.; Fong, P. Upward cascading effects of nutrients: shifts in a benthic microalgal community and a negative herbivore response. Oecologia 2004, 139, 560-567.

37. Jang, M.H.; Ha, K.; Takamura, N. Microcystin production by Microcystis aeruginosa exposed to different stages of herbivorous zooplankton. Toxicon 2008, 51, 882-889.

38. Utkilen, H.; Gjolme, N. Iron-stimulated toxin production in Microcystis aeruginosa. Appl. Environ. Microbiol. 1995, 61, 797-800.

39. Hooser, S.B. Fulminant hepatocyte apoptosis in vivo following microcystin-LR administration to rats. Toxicol. Pathol. 2000, 28, 726-733.

40. Weng, D.; Lu, Y.; Wei, Y.; Liu, Y.; Shen, P. The role of ROS in microcystin-LR-induced hepatocyte apoptosis and liver injury in mice. Toxicology 2007, 232, 15-23. 
41. Oberholster, P.J.; Myburgh, J.G.; Govender, D.; Bengis, R.; Botha, A.M. Identification of toxigenic Microcystis strains after incidents of wild animal mortalities in the Kruger National Park, South Africa. Ecotoxicol. Environ. Saf. 2009, 72, 1177-1182.

42. Fawell, J.K.; Mitchell, R.E.; Everett, D.J.; Hill, R.E. The toxicity of cyanobacterial toxins in the mouse: I microcystin-LR. Hum. Exp. Toxicol. 1999, 18, 162-167.

43. Miura, G.A.; Robinson, N.A.; Lawrence, W.B.; Pace, J.G. Hepatotoxicity of microcystin-LR in fed and fasted rats. Toxicon 1991, 29, 337-346.

44. Runnegar, M.; Berndt, N.; Kaplowitz, N. Microcystin uptake and inhibition of protein phosphatases: effects of chemoprotectants and self-inhibition in relation to known hepatic transporters. Toxicol. Appl. Pharmacol. 1995, 134, 264-272.

45. Clark, S.P.; Ryan, T.P.; Searfoss, G.H.; Davis, M.A.; Hooser, S.B. Chronic microcystin exposure induces hepatocyte proliferation with increased expression of mitotic and cyclin-associated genes in P53-deficient mice. Toxicol. Pathol. 2008, 36, 190-203.

46. Nishiwaki-Matsushima, R.; Ohta, T.; Nishiwaki, S.; Suganuma, M.; Kohyama, K.; Ishikawa, T.; Carmichael, W.W.; Fujiki, H. Liver tumor promotion by the cyanobacterial cyclic peptide toxin microcystin-LR. J. Cancer Res. Clin. Oncol. 1992, 118, 420-424.

47. Humpage, A.R.; Hardy, S.J.; Moore, E.J.; Froscio, S.M.; Falconer, I.R. Microcystins (cyanobacterial toxins) in drinking water enhance the growth of aberrant crypt foci in the mouse colon. J. Toxicol. Environ. Health A 2000, 61, 155-165.

48. Sekijima, M.; Tsutsumi, T.; Yoshida, T.; Harada, T.; Tashiro, F.; Chen, G.; Yu, S.Z.; Ueno, Y. Enhancement of glutathione S-transferase placental-form positive liver cell foci development by microcystin-LR in aflatoxin B1-initiated rats. Carcinogenesis 1999, 20, 161-165.

49. Lian, M.; Liu, Y.; Yu, S.Z.; Qian, G.S.; Wan, S.G.; Dixon, K.R. Hepatitis B virus x gene and cyanobacterial toxins promote aflatoxin B1-induced hepatotumorigenesis in mice. World J. Gastroenterol. 2006, 12, 3065-3072.

50. Carmichael, W.W.; Azevedo, S.M.; An, J.S.; Molica, R.J.; Jochimsen, E.M.; Lau, S.; Rinehart, K.L.; Shaw, G.R.; Eaglesham, G.K. Human fatalities from cyanobacteria: chemical and biological evidence for cyanotoxins. Environ. Health Perspect 2001, 109, 663-668.

51. Jochimsen, E.M.; Carmichael, W.W.; An, J.S.; Cardo, D.M.; Cookson, S.T.; Holmes, C.E.; Antunes, M.B.; de Melo Filho, D.A.; Lyra, T.M.; Barreto, V.S.; Azevedo, S.M.; Jarvis, W.R. Liver failure and death after exposure to microcystins at a hemodialysis center in Brazil. N. Engl. J. Med. 1998, 338, 873-878.

52. Yuan, M.; Carmichael, W.W.; Hilborn, E.D. Microcystin analysis in human sera and liver from human fatalities in Caruaru, Brazil 1996. Toxicon 2006, 48, 627-640.

53. Soares, R.M.; Yuan, M.; Servaites, J.C.; Delgado, A.; Magalhaes, V.F.; Hilborn, E.D.; Carmichael, W.W.; Azevedo, S.M. Sublethal exposure from microcystins to renal insufficiency patients in Rio de Janeiro, Brazil. Environ. Toxicol. 2006, 21, 95-103.

54. Ueno, Y.; Nagata, S.; Tsutsumi, T.; Hasegawa, A.; Watanabe, M.F.; Park, H.D.; Chen, G.C.; Chen, G.; Yu, S.Z. Detection of microcystins, a blue-green algal hepatotoxin, in drinking water sampled in Haimen and Fusui, endemic areas of primary liver cancer in China, by highly sensitive immunoassay. Carcinogenesis 1996, 17, 1317-1321. 
55. Svircev, Z.; Krstic, S.; Miladinov-Mikov, M.; Baltic, V.; Vidovic, M. Freshwater cyanobacterial blooms and primary liver cancer epidemiological studies in Serbia. J. Environ. Sci. Health C Environ. Carcinog. Ecotoxicol. Rev. 2009, 27, 36-55.

56. Cogliano, V.J.; Baan, R.A.; Straif, K.; Grosse, Y.; Secretan, B.; El Ghissassi, F. Use of mechanistic data in IARC evaluations. Environ. Mol. Mutagen 2008, 49, 100-109.

57. Hagenbuch, B.; Meier, P.J. Organic anion transporting polypeptides of the OATP/ SLC21 family: phylogenetic classification as OATP/SLCO superfamily, new nomenclature and molecular/functional properties. Pflugers Arch. 2004, 447, 653-665.

58. Fischer, W.J.; Altheimer, S.; Cattori, V.; Meier, P.J.; Dietrich, D.R.; Hagenbuch, B. Organic anion transporting polypeptides expressed in liver and brain mediate uptake of microcystin. Toxicol. Appl. Pharmacol. 2005, 203, 257-263.

59. Yoshida, T.; Makita, Y.; Tsutsumi, T.; Nagata, S.; Tashiro, F.; Yoshida, F.; Sekijima, M.; Tamura, S.; Harada, T.; Maita, K.; Ueno, Y. Immunohistochemical localization of microcystinLR in the liver of mice: a study on the pathogenesis of microcystin-LR-induced hepatotoxicity. Toxicol. Pathol. 1998, 26, 411-418.

60. Runnegar, M.T.; Kong, S.; Berndt, N. Protein phosphatase inhibition and in vivo hepatotoxicity of microcystins. Am. J. Physiol. 1993, 265, G224-G230.

61. Yoshizawa, S.; Matsushima, R.; Watanabe, M.F.; Harada, K.; Ichihara, A.; Carmichael, W.W.; Fujiki, H. Inhibition of protein phosphatases by microcystins and nodularin associated with hepatotoxicity. J. Cancer Res. Clin. Oncol. 1990, 116, 609-614.

62. Nong, Q.; Komatsu, M.; Izumo, K.; Indo, H.P.; Xu, B.; Aoyama, K.; Majima, H.J.; Horiuchi, M.; Morimoto, K.; Takeuchi, T. Involvement of reactive oxygen species in Microcystin-LR-induced cytogenotoxicity. Free Radic. Res. 2007, 41, 1326-1337.

63. MacKintosh, R.W.; Dalby, K.N.; Campbell, D.G.; Cohen, P.T.; Cohen, P.; MacKintosh, C. The cyanobacterial toxin microcystin binds covalently to cysteine-273 on protein phosphatase 1 . FEBS Lett. 1995, 371, 236-240.

64. Fischer, W.J.; Hitzfeld, B.C.; Tencalla, F.; Eriksson, J.E.; Mikhailov, A.; Dietrich, D.R. Microcystin-LR toxicodynamics, induced pathology, and immunohistochemical localization in livers of blue-green algae exposed rainbow trout (oncorhynchus mykiss). Toxicol. Sci. 2000, 54, $365-373$.

65. Lovell, R.A.; Schaeffer, D.J.; Hooser, S.B.; Haschek, W.M.; Dahlem, A.M.; Carmichael, W.W.; Beasley, V.R. Toxicity of intraperitoneal doses of microcystin-LR in two strains of male mice. $J$. Environ. Pathol. Toxicol. Oncol. 1989, 9, 221-237.

66. Yoshida, T.; Makita, Y.; Nagata, S.; Tsutsumi, T.; Yoshida, F.; Sekijima, M.; Tamura, S.; Ueno, Y. Acute oral toxicity of microcystin-LR, a cyanobacterial hepatotoxin, in mice. Nat. Toxins 1997, 5, 91-95.

67. Billam, M.; Mukhi, S.; Tang, L.; Gao, W.; Wang, J.S. Toxic response indicators of microcystinLR in F344 rats following a single-dose treatment. Toxicon 2008, 51, 1068-1080.

68. Ito, E.; Takai, A.; Kondo, F.; Masui, H.; Imanishi, S.; Harada, K. Comparison of protein phosphatase inhibitory activity and apparent toxicity of microcystins and related compounds. Toxicon 2002, 40, 1017-1025. 
69. Xing, Y.; Xu, Y.; Chen, Y.; Jeffrey, P.D.; Chao, Y.; Lin, Z.; Li, Z.; Strack, S.; Stock, J.B.; Shi, Y. Structure of protein phosphatase $2 \mathrm{~A}$ core enzyme bound to tumor-inducing toxins. Cell 2006, 127, 341-353.

70. Gehringer, M.M. Microcystin-LR and okadaic acid-induced cellular effects: a dualistic response. FEBS Lett. 2004, 557, 1-8.

71. Janssens, V.; Goris, J. Protein phosphatase 2A: a highly regulated family of serine/threonine phosphatases implicated in cell growth and signalling. Biochem. J. 2001, 353, 417-439.

72. Janssens, V.; Goris, J.; Van Hoof, C. PP2A: the expected tumor suppressor. Curr. Opin. Genet. Dev. 2005, 15, 34-41.

73. Zegura, B.; Zajc, I.; Lah, T.T.; Filipic, M. Patterns of microcystin-LR induced alteration of the expression of genes involved in response to DNA damage and apoptosis. Toxicon 2008, 51, $615-623$.

74. Zhan, L.; Sakamoto, H.; Sakuraba, M.; Wu, D.S.; Zhang, L.S.; Suzuki, T.; Hayashi, M.; Honma, M. Genotoxicity of microcystin-LR in human lymphoblastoid TK6 cells. Mutat. Res. 2004, 557, $1-6$.

75. Rao, P.V.; Bhattacharya, R. The cyanobacterial toxin microcystin-LR induced DNA damage in mouse liver in vivo. Toxicology 1996, 114, 29-36.

76. Runnegar, M.T.; Andrews, J.; Gerdes, R.G.; Falconer, I.R. Injury to hepatocytes induced by a peptide toxin from the cyanobacterium Microcystis aeruginosa. Toxicon 1987, 25, 1235-1239.

77. Zegura, B.; Lah, T.T.; Filipic, M. Alteration of intracellular GSH levels and its role in microcystin-LR-induced DNA damage in human hepatoma HepG2 cells. Mutat. Res. 2006, 611, 25-33.

78. Lankoff, A.; Banasik, A.; Nowak, M. Protective effect of melatonin against nodularin-induced oxidative stress. Arch. Toxicol. 2002, 76, 158-165.

79. Mikhailov, A.; Harmala-Brasken, A.S.; Hellman, J.; Meriluoto, J.; Eriksson, J.E. Identification of ATP-synthase as a novel intracellular target for microcystin-LR. Chem. Biol. Interact. 2003, 142, 223-237.

80. Chen, T.; Cui, J.; Liang, Y.; Xin, X.; Owen Young, D.; Chen, C.; Shen, P. Identification of human liver mitochondrial aldehyde dehydrogenase as a potential target for microcystin-LR. Toxicology 2006, 220, 71-80.

81. Mankiewicz, J.; Tarczynska, M.; Fladmark, K.E.; Doskeland, S.O.; Walter, Z.; Zalewski, M. Apoptotic effect of cyanobacterial extract on rat hepatocytes and human lymphocytes. Environ. Toxicol. 2001, 16, 225-233.

82. Ding, W.X.; Shen, H.M.; Ong, C.N. Critical role of reactive oxygen species and mitochondrial permeability transition in microcystin-induced rapid apoptosis in rat hepatocytes. Hepatology 2000, 32, 547-555.

83. Fladmark, K.E.; Brustugun, O.T.; Hovland, R.; Boe, R.; Gjertsen, B.T.; Zhivotovsky, B.; Doskeland, S.O. Ultrarapid caspase-3 dependent apoptosis induction by serine/threonine phosphatase inhibitors. Cell Death Differ. 1999, 6, 1099-1108.

84. Lin, S.S.; Bassik, M.C.; Suh, H.; Nishino, M.; Arroyo, J.D.; Hahn, W.C.; Korsmeyer, S.J.; Roberts, T.M. PP2A regulates BCL-2 phosphorylation and proteasome-mediated degradation at the endoplasmic reticulum. J. Biol. Chem. 2006, 281, 23003-23012. 
85. Tilli, M.T.; Hudgins, S.L.; Frech, M.S.; Halama, E.D.; Renou, J.P.; Furth, P.A. Loss of protein phosphatase 2A expression correlates with phosphorylation of DP-1 and reversal of dysplasia through differentiation in a conditional mouse model of cancer progression. Cancer Res. 2003, 63, 7668-7673.

86. Ding, W.X.; Nam Ong, C. Role of oxidative stress and mitochondrial changes in cyanobacteriainduced apoptosis and hepatotoxicity. FEMS Microbiol. Lett. 2003, 220, 1-7.

87. Ding, W.X.; Shen, H.M.; Zhu, H.G.; Lee, B.L.; Ong, C.N. Genotoxicity of microcystic cyanobacteria extract of a water source in China. Mutat. Res. 1999, 442, 69-77.

88. Hilgendorf, C.; Ahlin, G.; Seithel, A.; Artursson, P.; Ungell, A.L.; Karlsson, J. Expression of thirty-six drug transporter genes in human intestine, liver, kidney, and organotypic cell lines. Drug Metab. Dispos. 2007, 35, 1333-1340.

89. Ahlin, G.; Hilgendorf, C.; Karlsson, J.; Szigyarto, C.A.; Uhlen, M.; Artursson, P. Endogenous gene and protein expression of drug-transporting proteins in cell lines routinely used in drug discovery programs. Drug Metab. Dispos. 2009, 37, 2275-2283.

90. Boaru, D.A.; Dragos, N.; Schirmer, K. Microcystin-LR induced cellular effects in mammalian and fish primary hepatocyte cultures and cell lines: a comparative study. Toxicology 2006, 218, 134-148.

91. Lee, W.; Belkhiri, A.; Lockhart, A.C.; Merchant, N.; Glaeser, H.; Harris, E.I.; Washington, M.K.; Brunt, E.M.; Zaika, A.; Kim, R.B.; El-Rifai, W. Overexpression of OATP1B3 confers apoptotic resistance in colon cancer. Cancer Res. 2008, 68, 10315-10323.

92. Cui, Y.; Konig, J.; Nies, A.T.; Pfannschmidt, M.; Hergt, M.; Franke, W.W.; Alt, W.; Moll, R.; Keppler, D. Detection of the human organic anion transporters SLC21A6 (OATP2) and SLC21A8 (OATP8) in liver and hepatocellular carcinoma. Lab. Invest. 2003, 83, 527-538.

93. Abe, T.; Unno, M.; Onogawa, T.; Tokui, T.; Kondo, T.N.; Nakagomi, R.; Adachi, H.; Fujiwara, K.; Okabe, M.; Suzuki, T.; Nunoki, K.; Sato, E.; Kakyo, M.; Nishio, T.; Sugita, J.; Asano, N.; Tanemoto, M.; Seki, M.; Date, F.; Ono, K.; Kondo, Y.; Shiiba, K.; Suzuki, M.; Ohtani, H.; Shimosegawa, T.; Iinuma, K.; Nagura, H.; Ito, S.; Matsuno, S. LST-2, a human liver-specific organic anion transporter, determines methotrexate sensitivity in gastrointestinal cancers. Gastroenterology 2001, 120, 1689-1699.

94. Konig, J.; Seithel, A.; Gradhand, U.; Fromm, M.F. Pharmacogenomics of human OATP transporters. Naunyn Schmiedebergs Arch Pharmacol. 2006, 372, 432-443.

95. Tamai, I.; Nezu, J.; Uchino, H.; Sai, Y.; Oku, A.; Shimane, M.; Tsuji, A. Molecular identification and characterization of novel members of the human organic anion transporter (OATP) family. Biochem. Biophys. Res. Commun. 2000, 273, 251-260.

96. Bleasby, K.; Castle, J.C.; Roberts, C.J.; Cheng, C.; Bailey, W.J.; Sina, J.F.; Kulkarni, A.V.; Hafey, M.J.; Evers, R.; Johnson, J.M.; Ulrich, R.G.; Slatter, J.G. Expression profiles of 50 xenobiotic transporter genes in humans and pre-clinical species: a resource for investigations into drug disposition. Xenobiotica 2006, 36, 963-988.

97. Suzuki, T.; Onogawa, T.; Asano, N.; Mizutamari, H.; Mikkaichi, T.; Tanemoto, M.; Abe, M.; Satoh, F.; Unno, M.; Nunoki, K.; Suzuki, M.; Hishinuma, T.; Goto, J.; Shimosegawa, T.; Matsuno, S.; Ito, S.; Abe, T. Identification and characterization of novel rat and human gonadspecific organic anion transporters. Mol. Endocrinol. 2003, 17, 1203-1215. 
98. Lee, S.Y.; Williamson, B.; Caballero, O.L.; Chen, Y.T.; Scanlan, M.J.; Ritter, G.; Jongeneel, C.V.; Simpson, A.J.; Old, L.J. Identification of the gonad-specific anion transporter SLCO6A1 as a cancer/testis (CT) antigen expressed in human lung cancer. Cancer Immun. 2004, 4, 13.

99. Schiffer, R.; Neis, M.; Holler, D.; Rodriguez, F.; Geier, A.; Gartung, C.; Lammert, F.; Dreuw, A.; Zwadlo-Klarwasser, G.; Merk, H.; Jugert, F.; Baron, J.M. Active influx transport is mediated by members of the organic anion transporting polypeptide family in human epidermal keratinocytes. J. Invest. Dermatol. 2003, 120, 285-291.

100. Gao, B.; Huber, R.D.; Wenzel, A.; Vavricka, S.R.; Ismair, M.G.; Reme, C.; Meier, P.J. Localization of organic anion transporting polypeptides in the rat and human ciliary body epithelium. Exp. Eye Res. 2005, 80, 61-72.

101. Libra, A.; Fernetti, C.; Lorusso, V.; Visigalli, M.; Anelli, P.L.; Staud, F.; Tiribelli, C.; Pascolo, L. Molecular determinants in the transport of a bile acid-derived diagnostic agent in tumoral and nontumoral cell lines of human liver. J. Pharmacol. Exp. Ther. 2006, 319, 809-817.

102. Bronger, H.; Konig, J.; Kopplow, K.; Steiner, H.H.; Ahmadi, R.; Herold-Mende, C.; Keppler, D.; Nies, A.T. ABCC drug efflux pumps and organic anion uptake transporters in human gliomas and the blood-tumor barrier. Cancer Res. 2005, 65, 11419-11428.

103. Kalliokoski, A.; Niemi, M. Impact of OATP transporters on pharmacokinetics. Br. J. Pharmacol. 2009, 158, 693-705.

104. Franke, R.M.; Scherkenbach, L.A.; Sparreboom, A. Pharmacogenetics of the organic anion transporting polypeptide 1A2. Pharmacogenomics 2009, 10, 339-344.

105. Pizzagalli, F.; Varga, Z.; Huber, R.D.; Folkers, G.; Meier, P.J.; St-Pierre, M.V. Identification of steroid sulfate transport processes in the human mammary gland. J. Clin. Endocrinol. Metab. 2003, 88, 3902-3912.

106. Mikkaichi, T.; Suzuki, T.; Onogawa, T.; Tanemoto, M.; Mizutamari, H.; Okada, M.; Chaki, T.; Masuda, S.; Tokui, T.; Eto, N.; Abe, M.; Satoh, F.; Unno, M.; Hishinuma, T.; Inui, K.; Ito, S.; Goto, J.; Abe, T. Isolation and characterization of a digoxin transporter and its rat homologue expressed in the kidney. Proc. Natl. Acad. Sci. USA 2004, 101, 3569-3574.

107. Wlcek, K.; Svoboda, M.; Thalhammer, T.; Sellner, F.; Krupitza, G.; Jaeger, W. Altered expression of organic anion transporter polypeptide (OATP) genes in human breast carcinoma. Cancer Biol. Ther. 2008, 7, 1450-1455.

108. Martinez, F.O.; Gordon, S.; Locati, M.; Mantovani, A. Transcriptional profiling of the human monocyte-to-macrophage differentiation and polarization: new molecules and patterns of gene expression. J. Immunol. 2006, 177, 7303-7311.

109. Adachi, H.; Suzuki, T.; Abe, M.; Asano, N.; Mizutamari, H.; Tanemoto, M.; Nishio, T.; Onogawa, T.; Toyohara, T.; Kasai, S.; Satoh, F.; Suzuki, M.; Tokui, T.; Unno, M.; Shimosegawa, T.; Matsuno, S.; Ito, S.; Abe, T. Molecular characterization of human and rat organic anion transporter OATP-D. Am. J. Physiol. Renal Physiol. 2003, 285, F1188-F1197.

110. Umehara, K.; Iwai, M.; Adachi, Y.; Iwatsubo, T.; Usui, T.; Kamimura, H. Hepatic uptake and excretion of (-)- $N-\{2-[(R)-3-(6,7-$ dimethoxy-1,2,3,4-tetrahydroisoquinoline-2-carbonyl)p iperidino]ethyl -4-fluorobenzamide (YM758), a novel if channel inhibitor, in rats and humans. Drug Metab. Dispos. 2008, 36, 1030-1038. 
111. Huber, R.D.; Gao, B.; Sidler Pfandler, M.A.; Zhang-Fu, W.; Leuthold, S.; Hagenbuch, B.; Folkers, G.; Meier, P.J.; Stieger, B. Characterization of two splice variants of human organic anion transporting polypeptide 3A1 isolated from human brain. Am. J. Physiol. Cell Physiol. 2007, 292, C795-C806.

112. Janneh, O.; Hartkoorn, R.C.; Jones, E.; Owen, A.; Ward, S.A.; Davey, R.; Back, D.J.; Khoo, S.H. Cultured CD4T cells and primary human lymphocytes express hOATPs: intracellular accumulation of saquinavir and lopinavir. Br. J. Pharmacol. 2008, 155, 875-883.

113. Seki, S.; Kobayashi, M.; Itagaki, S.; Hirano, T.; Iseki, K. Contribution of organic anion transporting polypeptide OATP2B1 to amiodarone accumulation in lung epithelial cells. Biochim. Biophys. Acta 2009, 1788, 911-917.

114. Mandery, K.; Bujok, K.; Schmidt, I.; Wex, T.; Treiber, G.; Malfertheiner, P.; Rau, T.T.; Amann, K.U.; Brune, K.; Fromm, M.F.; Glaeser, H. Influence of cyclooxygenase inhibitors on the function of the prostaglandin transporter OATP2A1 expressed in human gastroduodenal mucosa. J. Pharmacol. Exp. Ther. 2010, 332, 345-351.

115. Niessen, J.; Jedlitschky, G.; Grube, M.; Bien, S.; Schwertz, H.; Ohtsuki, S.; Kawakami, H.; Kamiie, J.; Oswald, S.; Starke, K.; Strobel, U.; Siegmund, W.; Rosskopf, D.; Greinacher, A.; Terasaki, T.; Kroemer, H.K. Human platelets express organic anion-transporting peptide 2B1, an uptake transporter for atorvastatin. Drug Metab. Dispos. 2009, 37, 1129-1137.

116. Vavricka, S.R.; Jung, D.; Fried, M.; Grutzner, U.; Meier, P.J.; Kullak-Ublick, G.A. The human organic anion transporting polypeptide 8 (SLCO1B3) gene is transcriptionally repressed by hepatocyte nuclear factor 3beta in hepatocellular carcinoma. J. Hepatol. 2004, 40, 212-218.

117. Narita, M.; Hatano, E.; Arizono, S.; Miyagawa-Hayashino, A.; Isoda, H.; Kitamura, K.; Taura, K.; Yasuchika, K.; Nitta, T.; Ikai, I.; Uemoto, S. Expression of OATP1B3 determines uptake of Gd-EOB-DTPA in hepatocellular carcinoma. J. Gastroenterol. 2009, 44, 793-798.

118. Muto, M.; Onogawa, T.; Suzuki, T.; Ishida, T.; Rikiyama, T.; Katayose, Y.; Ohuchi, N.; Sasano, H.; Abe, T.; Unno, M. Human liver-specific organic anion transporter-2 is a potent prognostic factor for human breast carcinoma. Cancer Sci. 2007, 98, 1570-1576.

119. Liedauer, R.; Svoboda, M.; Wlcek, K.; Arrich, F.; Ja, W.; Toma, C.; Thalhammer, T. Different expression patterns of organic anion transporting polypeptides in osteosarcomas, bone metastases and aneurysmal bone cysts. Oncol. Rep. 2009, 22, 1485-1492.

120. Oba-Shinjo, S.M.; Caballero, O.L.; Jungbluth, A.A.; Rosemberg, S.; Old, L.J.; Simpson, A.J.; Marie, S.K. Cancer-testis (CT) antigen expression in medulloblastoma. Cancer Immun. 2008, 8, 7.

121. Burris, H.A., 3rd Shortcomings of current therapies for non-small-cell lung cancer: unmet medical needs. Oncogene 2009, 28 (Suppl 1), S4-S13.

122. Saltz, L.B. Progress in cancer care: the hope, the hype, and the gap between reality and perception. J. Clin. Oncol. 2008, 26, 5020-5021.

123. Philip, P.A.; Mooney, M.; Jaffe, D.; Eckhardt, G.; Moore, M.; Meropol, N.; Emens, L.; O'Reilly, E.; Korc, M.; Ellis, L.; Benedetti, J.; Rothenberg, M.; Willett, C.; Tempero, M.; Lowy, A.; Abbruzzese, J.; Simeone, D.; Hingorani, S.; Berlin, J.; Tepper, J. Consensus report of the national cancer institute clinical trials planning meeting on pancreas cancer treatment. J. Clin. Oncol. 2009, 27, 5660-5669. 
124. Hotchkiss, R.S.; Strasser, A.; McDunn, J.E.; Swanson, P.E. Cell death. N. Engl. J. Med. 2009, $361,1570-1583$.

125. Rosen, J.M.; Jordan, C.T. The increasing complexity of the cancer stem cell paradigm. Science 2009, 324, 1670-1673.

126. Roukos, D.H.; Murray, S.; Briasoulis, E. Molecular genetic tools shape a roadmap towards a more accurate prognostic prediction and personalized management of cancer. Cancer Biol. Ther. 2007, 6, 308-312.

127. Gupta, P.B.; Onder, T.T.; Jiang, G.; Tao, K.; Kuperwasser, C.; Weinberg, R.A.; Lander, E.S. Identification of selective inhibitors of cancer stem cells by high-throughput screening. Cell 2009, 138, 645-659.

128. Gatenby, R.A. A change of strategy in the war on cancer. Nature 2009, 459, 508-509.

129. Briasoulis, E.; Pavlidis, N.; Terret, C.; Bauer, J.; Fiedler, W.; Schoffski, P.; Raoul, J.L.; Hess, D.; Selvais, R.; Lacombe, D.; Bachmann, P.; Fumoleau, P. Glufosfamide administered using a 1hour infusion given as first-line treatment for advanced pancreatic cancer. A phase II trial of the EORTC-new drug development group. Eur. J. Cancer 2003, 39, 2334-2340.

130. Briasoulis, E.; Judson, I.; Pavlidis, N.; Beale, P.; Wanders, J.; Groot, Y.; Veerman, G.; Schuessler, M.; Niebch, G.; Siamopoulos, K.; Tzamakou, E.; Rammou, D.; Wolf, L.; Walker, R.; Hanauske, A. Phase I trial of 6-hour infusion of glufosfamide, a new alkylating agent with potentially enhanced selectivity for tumors that overexpress transmembrane glucose transporters: a study of the European Organization for Research and Treatment of Cancer Early Clinical Studies Group. J. Clin. Oncol. 2000, 18, 3535-3544.

131. Laidley, C.W.; Cohen, E.; Casida, J.E. Protein phosphatase in neuroblastoma cells: $[3 \mathrm{H}]$ cantharidin binding site in relation to cytotoxicity. J. Pharmacol. Exp. Ther. 1997, 280, 1152-1158.

132. Driggers, E.M.; Hale, S.P.; Lee, J.; Terrett, N.K. The exploration of macrocycles for drug discovery--an underexploited structural class. Nat. Rev. Drug Discov. 2008, 7, 608-624.

133. Robinson, N.A.; Pace, J.G.; Matson, C.F.; Miura, G.A.; Lawrence, W.B. Tissue distribution, excretion and hepatic biotransformation of microcystin-LR in mice. J. Pharmacol. Exp. Ther. 1991, 256, 176-182.

134. Daily, A.; Monks, N.R.; Leggas, M.; Moscow, J.A. Abrogation of microcystin cytotoxicity by MAP kinase inhibitors and $N$-acetyl cysteine is confounded by OATPIB1 uptake activity inhibition. Toxicon 2010, 55, 827-837.

135. Stotts, R.R.; Namikoshi, M.; Haschek, W.M.; Rinehart, K.L.; Carmichael, W.W.; Dahlem, A.M.; Beasley, V.R. Structural modifications imparting reduced toxicity in microcystins from Microcystis spp. Toxicon 1993, 31, 783-789.

136. Goldberg, J.; Huang, H.B.; Kwon, Y.G.; Greengard, P.; Nairn, A.C.; Kuriyan, J. Threedimensional structure of the catalytic subunit of protein serine/threonine phosphatase-1. Nature 1995, 376, 745-753.

137. Craig, M.; Luu, H.A.; McCready, T.L.; Williams, D.; Andersen, R.J.; Holmes, C.F. Molecular mechanisms underlying he interaction of motuporin and microcystins with type-1 and type-2A protein phosphatases. Biochem. Cell Biol. 1996, 74, 569-578. 
138. Maynes, J.T.; Luu, H.A.; Cherney, M.M.; Andersen, R.J.; Williams, D.; Holmes, C.F.; James, M.N. Crystal structures of protein phosphatase-1 bound to motuporin and dihydromicrocystinLA: elucidation of the mechanism of enzyme inhibition by cyanobacterial toxins. J. Mol. Biol. 2006, 356, 111-120.

139. Humphrey, J.M.; Aggen, J.B.; Chamberlin, A.R. Total Synthesis of the Serine-Threonine Phosphatase Inhibitor Microcystin-LA. J. Am. Chem. Soc. 1996, 118, 11759-11770.

140. Aggen, J.B.; Humphrey, J.M.; Gauss, C.M.; Huang, H.B.; Nairn, A.C.; Chamberlin, A.R. The design, synthesis, and biological evaluation of analogues of the serine-threonine protein phosphatase 1 and 2A selective inhibitor microcystin LA: rational modifications imparting PP1 selectivity. Bioorg. Med. Chem. 1999, 7, 543-564.

141. Gulledge, B.M.; Aggen, J.B.; Chamberlin, A.R. Linearized and truncated microcystin analogues as inhibitors of protein phosphatases 1 and 2A. Bioorg. Med. Chem. Lett. 2003, 13, 2903-2906.

142. Abdel-Rahman, S.; el-Ayouty, Y.M.; Kamael, H.A. Characterization of heptapeptide toxins extracted from Microcystis aeruginosa (Egyptian isolate). Comparison with some synthesized analogs. Int. J. Pept. Protein Res. 1993, 41, 1-7.

143. Taylor, C.; Quinn, R.J.; Suganuma, M.; Fujiki, H. Inhibition of protein phosphatase 2A by cyclic peptides modeled on the microcystin ring. Bioorg. Med. Chem. Lett. 1996, 6, 2113-2116.

144. Tappan, E.; Chamberlin, A.R. Activation of protein phosphatase 1 by a small molecule designed to bind to the enzyme's regulatory site. Chem. Biol. 2008, 15, 167-174.

145. Kondo, F.; Matsumoto, H.; Yamada, S.; Ishikawa, N.; Ito, E.; Nagata, S.; Ueno, Y.; Suzuki, M.; Harada, K. Detection and identification of metabolites of microcystins formed in vivo in mouse and rat livers. Chem. Res. Toxicol. 1996, 9, 1355-1359.

146. Trogen, G.B.; Edlund, U.; Larsson, G.; Sethson, I. The solution NMR structure of a blue-green algae hepatotoxin, microcystin-RR--a comparison with the structure of microcystin-LR. Eur. J. Biochem. 1998, 258, 301-312.

147. Bagu, J.R.; Sykes, B.D.; Craig, M.M.; Holmes, C.F. A molecular basis for different interactions of marine toxins with protein phosphatase-1. Molecular models for bound motuporin, microcystins, okadaic acid, and calyculin A. J. Biol. Chem. 1997, 272, 5087-5097.

148. Bagu, J.R.; Sonnichsen, F.D.; Williams, D.; Andersen, R.J.; Sykes, B.D.; Holmes, C.F. Comparison of the solution structures of microcystin-LR and motuporin. Nat. Struct. Biol. 1995, 2, 114-116.

149. Lavigne, P.; Bagu, J.R.; Boyko, R.; Willard, L.; Holmes, C.F.; Sykes, B.D. Structure-based thermodynamic analysis of the dissociation of protein phosphatase-1 catalytic subunit and microcystin-LR docked complexes. Protein Sci. 2000, 9, 252-264.

150. Nishizawa, T.; Asayama, M.; Fujii, K.; Harada, K.; Shirai, M. Genetic analysis of the peptide synthetase genes for a cyclic heptapeptide microcystin in Microcystis spp. J. Biochem. 1999, $126,520-529$.

151. Nishizawa, T.; Ueda, A.; Asayama, M.; Fujii, K.; Harada, K.; Ochi, K.; Shirai, M. Polyketide synthase gene coupled to the peptide synthetase module involved in the biosynthesis of the cyclic heptapeptide microcystin. J. Biochem. 2000, 127, 779-789. 
152. Tillett, D.; Dittmann, E.; Erhard, M.; von Dohren, H.; Borner, T.; Neilan, B.A. Structural organization of microcystin biosynthesis in Microcystis aeruginosa PCC7806: an integrated peptide-polyketide synthetase system. Chem. Biol. 2000, 7, 753-764.

153. Christiansen, G.; Fastner, J.; Erhard, M.; Borner, T.; Dittmann, E. Microcystin biosynthesis in planktothrix: genes, evolution, and manipulation. J. Bacteriol. 2003, 185, 564-572.

154. Rouhiainen, L.; Vakkilainen, T.; Siemer, B.L.; Buikema, W.; Haselkorn, R.; Sivonen, K. Genes coding for hepatotoxic heptapeptides (microcystins) in the cyanobacterium Anabaena strain 90. Appl. Environ. Microbiol. 2004, 70, 686-692.

155. Marahiel, M.A.; Stachelhaus, T.; Mootz, H.D. Modular Peptide Synthetases Involved in Nonribosomal Peptide Synthesis. Chem. Rev. 1997, 97, 2651-2674.

156. Sieber, S.A.; Marahiel, M.A. Molecular mechanisms underlying nonribosomal peptide synthesis: approaches to new antibiotics. Chem. Rev. 2005, 105, 715-738.

157. Mikalsen, B.; Boison, G.; Skulberg, O.M.; Fastner, J.; Davies, W.; Gabrielsen, T.M.; Rudi, K.; Jakobsen, K.S. Natural variation in the microcystin synthetase operon mcyABC and impact on microcystin production in Microcystis strains. J. Bacteriol. 2003, 185, 2774-2785.

158. Tanabe, Y.; Sano, T.; Kasai, F.; Watanabe, M.M. Recombination, cryptic clades and neutral molecular divergence of the microcystin synthetase (mcy) genes of toxic cyanobacterium Microcystis aeruginosa. BMC Evol. Biol. 2009, 9, 115.

159. Lautru, S.; Challis, G.L. Substrate recognition by nonribosomal peptide synthetase multienzymes. Microbiology 2004, 150, 1629-1636.

160. Fewer, D.P.; Rouhiainen, L.; Jokela, J.; Wahlsten, M.; Laakso, K.; Wang, H.; Sivonen, K. Recurrent adenylation domain replacement in the microcystin synthetase gene cluster. BMC Evol. Biol. 2007, 7, 183.

161. Stachelhaus, T.; Mootz, H.D.; Marahiel, M.A. The specificity-conferring code of adenylation domains in nonribosomal peptide synthetases. Chem. Biol. 1999, 6, 493-505.

162. Lautru, S.; Deeth, R.J.; Bailey, L.M.; Challis, G.L. Discovery of a new peptide natural product by Streptomyces coelicolor genome mining. Nat. Chem. Biol. 2005, 1, 265-269.

163. Mootz, H.D.; Schwarzer, D.; Marahiel, M.A. Construction of hybrid peptide synthetases by module and domain fusions. Proc. Natl. Acad. Sci. USA 2000, 97, 5848-5853.

164. Tanovic, A.; Samel, S.A.; Essen, L.O.; Marahiel, M.A. Crystal structure of the termination module of a nonribosomal peptide synthetase. Science 2008, 321, 659-663.

165. Yonus, H.; Neumann, P.; Zimmermann, S.; May, J.J.; Marahiel, M.A.; Stubbs, M.T. Crystal structure of DltA. Implications for the reaction mechanism of non-ribosomal peptide synthetase adenylation domains. J. Biol. Chem. 2008, 283, 32484-32491.

166. Koglin, A.; Lohr, F.; Bernhard, F.; Rogov, V.V.; Frueh, D.P.; Strieter, E.R.; Mofid, M.R.; Guntert, P.; Wagner, G.; Walsh, C.T.; Marahiel, M.A.; Dotsch, V. Structural basis for the selectivity of the external thioesterase of the surfactin synthetase. Nature 2008, 454, 907-911.

167. Frueh, D.P.; Arthanari, H.; Koglin, A.; Vosburg, D.A.; Bennett, A.E.; Walsh, C.T.; Wagner, G. Dynamic thiolation-thioesterase structure of a non-ribosomal peptide synthetase. Nature 2008, 454, 903-906. 
168. Lai, J.R.; Fischbach, M.A.; Liu, D.R.; Walsh, C.T. A protein interaction surface in nonribosomal peptide synthesis mapped by combinatorial mutagenesis and selection. Proc. Natl. Acad. Sci. USA 2006, 103, 5314-5319.

169. Watanabe, K.; Hotta, K.; Praseuth, A.P.; Koketsu, K.; Migita, A.; Boddy, C.N.; Wang, C.C.; Oguri, H.; Oikawa, H. Total biosynthesis of antitumor nonribosomal peptides in Escherichia coli. Nat. Chem. Biol. 2006, 2, 423-428.

170. Miyahisa, I.; Kaneko, M.; Funa, N.; Kawasaki, H.; Kojima, H.; Ohnishi, Y.; Horinouchi, S. Efficient production of (2S)-flavanones by Escherichia coli containing an artificial biosynthetic gene cluster. Appl. Microbiol. Biotechnol. 2005, 68, 498-504.

171. Ma, S.M.; Li, J.W.; Choi, J.W.; Zhou, H.; Lee, K.K.; Moorthie, V.A.; Xie, X.; Kealey, J.T.; Da Silva, N.A.; Vederas, J.C.; Tang, Y. Complete reconstitution of a highly reducing iterative polyketide synthase. Science 2009, 326, 589-592.

172. Santra, A.; Chowdhury, A.; Ghatak, S.; Biswas, A.; Dhali, G.K. Arsenic induces apoptosis in mouse liver is mitochondria dependent and is abrogated by $\mathrm{N}$-acetylcysteine. Toxicol. Appl. Pharmacol. 2007, 220, 146-155.

173. Puerto, M.; Prieto, A.I.; Pichardo, S.; Moreno, I.; Jos, A.; Moyano, R.; Camean, A.M. Effects of dietary $\mathrm{N}$-acetylcysteine on the oxidative stress induced in tilapia (Oreochromis Niloticus) exposed to a microcystin-producing cyanobacterial water bloom. Environ. Toxicol. Chem. 2009, 28, 1679-1686.

174. Kortsalioudaki, C.; Taylor, R.M.; Cheeseman, P.; Bansal, S.; Mieli-Vergani, G.; Dhawan, A. Safety and efficacy of $\mathrm{N}$-acetylcysteine in children with non-acetaminophen-induced acute liver failure. Liver Transpl. 2008, 14, 25-30.

175. Terneus, M.V.; Brown, J.M.; Carpenter, A.B.; Valentovic, M.A. Comparison of $S$-adenosyl-Lmethionine (SAMe) and $N$-acetylcysteine (NAC) protective effects on hepatic damage when administered after acetaminophen overdose. Toxicology 2008, 244, 25-34.

176. Manov, I.; Hirsh, M.; Iancu, T.C. $N$-acetylcysteine does not protect HepG2 cells against acetaminophen-induced apoptosis. Basic Clin. Pharmacol. Toxicol. 2004, 94, 213-225.

177. Campos, A.; Vasconcelos, V. Molecular mechanisms of microcystin toxicity in animal cells. Int. J. Mol. Sci. 2010, 11, 268-287.

178. Trachootham, D.; Alexandre, J.; Huang, P. Targeting cancer cells by ROS-mediated mechanisms: a radical therapeutic approach? Nat. Rev. Drug Discov. 2009, 8, 579-591.

179. Pelicano, H.; Carney, D.; Huang, P. ROS stress in cancer cells and therapeutic implications. Drug Resist. Updat. 2004, 7, 97-110.

180. Schumacker, P.T. Reactive oxygen species in cancer cells: live by the sword, die by the sword. Cancer Cell 2006, 10, 175-176.

181. Trachootham, D.; Zhou, Y.; Zhang, H.; Demizu, Y.; Chen, Z.; Pelicano, H.; Chiao, P.J.; Achanta, G.; Arlinghaus, R.B.; Liu, J.; Huang, P. Selective killing of oncogenically transformed cells through a ROS-mediated mechanism by beta-phenylethyl isothiocyanate. Cancer Cell 2006, 10, 241-252.

182. Treiber, A.; Schneiter, R.; Hausler, S.; Stieger, B. Bosentan is a substrate of human OATP1B1 and OATP1B3: inhibition of hepatic uptake as the common mechanism of its interactions with cyclosporin A, rifampicin, and sildenafil. Drug Metab. Dispos. 2007, 35, 1400-1407. 
183. He, Y.J.; Zhang, W.; Chen, Y.; Guo, D.; Tu, J.H.; Xu, L.Y.; Tan, Z.R.; Chen, B.L.; Li, Z.; Zhou, G.; Yu, B.N.; Kirchheiner, J.; Zhou, H.H. Rifampicin alters atorvastatin plasma concentration on the basis of SLCO1B1 521T>C polymorphism. Clin. Chim. Acta 2009, 405, 49-52.

184. Ogasawara, M.A.; Zhang, H. Redox regulation and its emerging roles in stem cells and stem-like cancer cells. Antioxid. Redox Signal. 2009, 11, 1107-1122.

185. Ito, K.; Oleschuk, C.J.; Westlake, C.; Vasa, M.Z.; Deeley, R.G.; Cole, S.P. Mutation of Trp1254 in the multispecific organic anion transporter, multidrug resistance protein 2 (MRP2) (ABCC2), alters substrate specificity and results in loss of methotrexate transport activity. J. Biol. Chem. 2001, 276, 38108-38114.

186. Klaassen, C.D.; Lu, H. Xenobiotic transporters: ascribing function from gene knockout and mutation studies. Toxicol. Sci. 2008, 101, 186-196.

187. Janga, S.C.; Tzakos, A. Structure and organization of drug-target networks: insights from genomic approaches for drug discovery. Mol. Biosyst. 2009, 5, 1536-1548.

188. Barglow, K.T.; Cravatt, B.F. Activity-based protein profiling for the functional annotation of enzymes. Nat. Methods 2007, 4, 822-827.

Sample Availability: Available from the authors.

(C) 2010 by the authors; licensee Molecular Diversity Preservation International, Basel, Switzerland.

This article is an open-access article distributed under the terms and conditions of the Creative Commons Attribution license (http://creativecommons.org/licenses/by/3.0/). 